\title{
UK Renal Registry 16th Annual Report: Chapter 10 Haemoglobin, Ferritin and Erythropoietin amongst UK Adult Dialysis Patients in 2012: National and Centre-specific Analyses
}

\author{
Anirudh Rao ${ }^{a}$, Julie Gilg ${ }^{a}$, Andrew Williams ${ }^{b}$ \\ aUK Renal Registry, Bristol, UK; ${ }^{\text {b}}$ Morriston Hospital, Swansea, UK
}

\section{Key Words}

Anaemia - Chronic kidney disease - Dialysis - End stage renal disease . Epidemiology · Erythropoietin - Erythropoietin stimulating agent . European Best Practice Guidelines . Ferritin - Haemodialysis - Haemoglobin - NICE - Peritoneal dialysis - Renal Association

\begin{abstract}
Introduction: Anaemia treatment in chronic kidney disease (CKD) patients has changed dramatically since the implementation of erythropoietin stimulating agents (ESAs) and has shifted the emphasis from treating severe anaemia in dialysis patients to preventing anaemia. The aim of this chapter is to determine the extent to which the UK Renal Association (RA) and National Institute for Health and Care Excellence (NICE) guidelines for anaemia management are met in the UK. Methods: Quarterly data were obtained for haemoglobin $(\mathrm{Hb})$ and factors that influence $\mathrm{Hb}$ from UK renal centres for the incident and prevalent renal replacement therapy (RRT) cohorts for
\end{abstract}

2012. Results: In the UK, in 2012, 51\% of patients commenced dialysis therapy with $\mathrm{Hb} 100 \mathrm{~g} / \mathrm{L}$ (median $\mathrm{Hb}$ $100 \mathrm{~g} / \mathrm{L}$ ). Of patients in the early presentation group, 54\% started dialysis with $\mathrm{Hb} 100 \mathrm{~g} / \mathrm{L}$ whilst $34 \%$ of patients presenting late started dialysis with $\mathrm{Hb} 100 \mathrm{~g} / \mathrm{L}$. The UK median $\mathrm{Hb}$ of haemodialysis (HD) patients was $112 \mathrm{~g} / \mathrm{L}$, with $82 \%$ of patients having $\mathrm{Hb} 100 \mathrm{~g} / \mathrm{L}$. The median $\mathrm{Hb}$ of peritoneal dialysis (PD) patients in the UK was $114 \mathrm{~g} / \mathrm{L}$, with $85 \%$ of patients having $\mathrm{Hb} 100 \mathrm{~g} / \mathrm{L}$. The median ferritin in $\mathrm{HD}$ patients in the UK was $431 \mu \mathrm{g} / \mathrm{L}$ and $95 \%$ of HD patients had a ferritin $100 \mu \mathrm{g} / \mathrm{L}$. In EW\&NI the median ferritin in PD patients was $285 \mu \mathrm{g} / \mathrm{L}$ (IQR 164-466) with $88 \%$ of PD patients having a ferritin $100 \mu \mathrm{g} / \mathrm{L}$. In EW\&NI the median ESA dose was higher for HD than PD patients (7,248 vs. 4,250 IU/week). The percentage of patients treated with an ESA and having $\mathrm{Hb}>120 \mathrm{~g} / \mathrm{L}$ ranged between centres from $7-39 \%$ for HD and from $0-33 \%$ for PD. Conclusions: There was poor correlation between median $\mathrm{Hb}$ achieved and median ferritin and ESA usage across the EW\&NI centres. There was also a significant variation between centres in the percentages of patients treated with an ESA and having $\mathrm{Hb}>120 \mathrm{~g} / \mathrm{L}$.

$\begin{array}{ll}\text { KARGER } & \text { C 2014 S. Karger AG, Basel } \\ \text { Fax +4161 306 1234 } & \text { 1160-2110/14/1254-0183\$38.00/0 } \\ \begin{array}{l}\text { E-Mail karger@karger.com } \\ \text { www.karger.com }\end{array} & \begin{array}{l}\text { Accessible online at: } \\ \text { www.karger.com/nec }\end{array}\end{array}$

Anirudh Rao

UK Renal Registry, Southmead Hospital, Southmead Road, Bristol, BS10 5NB, UK

Email: renalregistry@renalregistry.nhs.uk 


\section{Introduction}

This chapter describes the UK Renal Registry (UKRR) data relating to the management of anaemia in dialysis patients during 2012. The chapter reports on the analyses of submitted variables in the context of the UK Renal Association - Anaemia in CKD guidelines and recommendations.

In this report, haemoglobin levels are given in $\mathrm{g} / \mathrm{L}$ as the majority of UK laboratories have now switched to reporting using these units.

Anaemia in adults with CKD is diagnosed when the $\mathrm{Hb}$ concentration is $<130 \mathrm{~g} / \mathrm{L}$ in males and $<120 \mathrm{~g} / \mathrm{L}$ in females [1]. The degree of renal impairment affects the likelihood of any patient developing anaemia. Although current treatment with ESAs is not recommended unless $\mathrm{Hb}$ falls consistently below $110 \mathrm{~g} / \mathrm{L}$, other causes of anaemia should be excluded in patients with $\mathrm{Hb}$ below the normal range.

The renal National Service Framework (NSF) part one [2] and the RA minimum standards document 3rd edition [3] state that individuals with chronic kidney disease (CKD) should achieve a haemoglobin $(\mathrm{Hb})$ of at least $100 \mathrm{~g} / \mathrm{L}$ within six months of being seen by a nephrologist, unless there is a specific reason why it is unachievable. The UKRR does not collect $\mathrm{Hb}$ measurements from patients with CKD six months after meeting a nephrologist. However, an indication of the attainment of this standard is given by the $\mathrm{Hb}$ of the incident patient population at the start of dialysis. Achievement of these standards is mainly through the use of iron therapy (oral and intravenous) and erythropoietin stimulating agents (ESAs).

The European Best Practice Guidelines (EBPG) published in 2009 recommend that $\mathrm{Hb}$ values of 110 $120 \mathrm{~g} / \mathrm{L}$ should be generally sought in the CKD population without intentionally exceeding $130 \mathrm{~g} / \mathrm{L}$ [4]. The 5th edition of the UK Renal Association's Anaemia in CKD guideline was published at the end of 2010 and attempted to unify targets with those published in the 2011 update NICE guideline on anaemia management in CKD and other guidelines $[5,6]$. The target outcome $\mathrm{Hb}$ for RRT patients on ESA treatment in these guidelines is between 100 and $120 \mathrm{~g} / \mathrm{L}$. The rationale behind choosing a wide target $\mathrm{Hb}$ range $(100-120 \mathrm{~g} / \mathrm{L})$ is that when the target $\mathrm{Hb}$ level is narrow (e.g. $100 \mathrm{~g} / \mathrm{L}$ ), variability in achieved $\mathrm{Hb}$ levels around the target is high, the proportion of prevalent patients with achieved $\mathrm{Hb}$ levels within the target range is low and ESA dose titration is required frequently during maintenance therapy. The recently updated KDOQI guidelines suggest ESAs should not be used to maintain $\mathrm{Hb}$ concentration routinely above $115 \mathrm{~g} / \mathrm{L}$ with careful consideration in patients who require individualization of therapy for improvements in quality of life at $\mathrm{Hb}$ concentration above $115 \mathrm{~g} / \mathrm{L}$ [7]. The target of $\mathrm{Hb} 100-120 \mathrm{~g} / \mathrm{L}$ has been used for both HD and PD patients in keeping with the above recommendations. There are also some analyses showing attainment of the minimum standard of $\mathrm{Hb}$ $100 \mathrm{~g} / \mathrm{L}$.

In patients on peritoneal dialysis (PD), the timing of the blood sample draw is not critical because plasma volume in these patients remains relatively constant. In haemodialysis (HD) patients, interdialytic weight gain contributes to a decrease in $\mathrm{Hb}$ level, whereas intradialytic ultrafiltration leads to an increase. Thus, a predialysis sample underestimates the euvolaemic $\mathrm{Hb}$ level, whereas a postdialysis sample overestimates the euvolaemic $\mathrm{Hb}$. Given the relationship between $\mathrm{Hb}$ level and the dialysis related weight change, midweek pre-dialysis sampling is recommended for regular $\mathrm{Hb}$ monitoring [8].

The 2010 Renal Association (RA) Clinical Practice Guidelines document, revised European Best Practice Guidelines (EBPGII), Dialysis Outcomes Quality Initiative (DOQI) guidelines and UK NICE anaemia guidelines all recommend a target serum ferritin greater than $100 \mu \mathrm{g} / \mathrm{L}$ and percentage transferrin saturation (TSAT) of more than $20 \%$ in patients with CKD. RA guidelines and EBPGII recommend hypochromic red cells (HRC) less than $10 \%$. In addition, EBPGII recommends target reticulocyte $\mathrm{Hb}$ content $(\mathrm{CHr})$ of greater than $29 \mathrm{pg} / \mathrm{cell}$. KDOQI recommends a serum ferritin $>200 \mu \mathrm{g} / \mathrm{L}$ for HD patients. The NICE guidelines suggest that a hypochromic red cell value $>6 \%$ indicates ongoing iron deficiency.

To achieve adequate iron status across a patient population, RA guidelines [6] advocate population target medians for ferritin of $200-500 \mu \mathrm{g} / \mathrm{L}$ in $\mathrm{HD}$ patients and $100-500 \mu \mathrm{g} / \mathrm{L}$ for PD patients, for TSAT of 30 $40 \%$, for hypochromic red cells of $<2.5 \%$ and $\mathrm{CHr}$ of $35 \mathrm{pg} / \mathrm{cell}$. EBPGII comments that a serum ferritin target for the treatment population of $200-500 \mu \mathrm{g} / \mathrm{L}$ ensures that $85-90 \%$ of patients attain a serum ferritin of $100 \mu \mathrm{g} / \mathrm{L}$. All guidelines advise that serum ferritin levels should not exceed $800 \mu \mathrm{g} / \mathrm{L}$ since the potential risk of toxicity increases without conferring additional benefit. The KDOQI and NICE guidelines advise against intravenous iron administration to patients with a ferritin $>500 \mu \mathrm{g} / \mathrm{L}$.

Serum ferritin has some disadvantages as an index of iron status. It measures storage iron rather than available 
iron, behaves as an acute phase reactant and is therefore increased in inflammatory states, malignancy and liver disease and may not accurately reflect iron stores if measured within a week of the administration of intravenous iron. Serum ferritin level is less reliable in the evaluation of iron stores in HD patients, because ferritin level is affected by other factors in addition to iron storage status. In relatively healthy HD patients, before widespread use of IV iron therapy, the finding of a ferritin level less than $50 \mathrm{ng} / \mathrm{ml}$ was not uncommon and was associated with absent bone marrow iron in approximately $80 \%$ of patients. However, in HD patients with several comorbidities, absent iron stores may still be found at ferritin levels approaching or even exceeding $200 \mathrm{ng} / \mathrm{ml}$ [9].

Of the alternative measures of iron status available, HRC and $\mathrm{CHr}$ are generally considered superior to TSAT. Both however require specialised analysers to which not all UK renal centres have easy access. Since TSAT is measured infrequently in many centres and most UK centres continue to use serum ferritin for routine iron management, ferritin remains the chosen index of iron status for this report.

Anaemia treatment in CKD patients has changed dramatically since the implementation of erythropoietin stimulating agents (ESAs) into clinical practice in 1987. This has reduced the need for blood transfusions and improved quality of life for patients [10]. These agents are relatively expensive and thus approaches to achieving optimal haemoglobin levels with the lowest possible doses are desirable. The health economics of anaemia therapy using ESAs has been subject to a NICE systematic review [5] which concluded that treating to a target $\mathrm{Hb}$ $110-120 \mathrm{~g} / \mathrm{L}$ is cost effective in HD patients.

The risks associated with low $(<100 \mathrm{~g} / \mathrm{L})$ and high $(>130 \mathrm{~g} / \mathrm{L}) \mathrm{Hb}$ are not necessarily equivalent. Two important studies of patients not yet on dialysis, CHOIR [11] and CREATE [12] showed an increased risk of cardiovascular events amongst the patients assigned to the higher $\mathrm{Hb}$ targets. In the TREAT study [13] although there was no difference between the two arms in the primary outcome of death, cardiovascular event or end stage renal disease, there was an increase in fatal or non-fatal stroke in the treatment arm.

\section{Methods}

The incident and prevalent RRT cohorts for 2012 were analysed. The UKRR extracted quarterly data electronically from renal centres in England, Wales and Northern Ireland; data from Scotland were provided by the Scottish Renal Registry.

For the analyses of $\mathrm{Hb}$ for incident patients, those patients commencing RRT on PD or HD were included whilst those receiving a pre-emptive transplant were excluded. Hb measurements from after starting dialysis but still within the same quarter of the year were used. Therefore, depending on when in the quarter a patient started RRT the $\mathrm{Hb}$ could be from 0 to 90 days later. The haemoglobin values the UKRR receives should be the closest available measurement to the end of the quarter. Patients who died within the first 90 days on treatment were excluded. Results are also shown with the cohort subdivided into early and late presenters (date first seen by a nephrologist, 90 or more days and less than 90 days before starting dialysis respectively).

For the analyses of prevalent patients, those patients receiving dialysis on 31st December 2012 were included if they had been on the same modality of dialysis in the same centre for at least three months. In order to improve completeness the last available measurement for each patient from the last two quarters for $\mathrm{Hb}$ and from the last three quarters for ferritin was used. Scotland was excluded from the analysis for ferritin for PD patients as this data was not available.

The completeness of data items were analysed at both centre and country level. As in previous years, all patients were included in analyses but centres with less than $50 \%$ completeness were excluded from the caterpillar and funnel plots showing centre performance. Centres providing relevant data from less than 10 patients were also excluded from the plots. The number preceding the centre name in the caterpillar plots indicates the percentage of data missing for that centre.

The data were analysed to calculate summary statistics including maximum, minimum and average (mean and median) values. Standard deviations and inter-quartile ranges (IQR) were also calculated. These are shown using caterpillar plots giving median values and the inter-quartile ranges.

The percentages achieving RA and other standards were calculated for $\mathrm{Hb}$ and ferritin. These are displayed using caterpillar plots with the percentages meeting the targets and 95\% confidence intervals (CIs) shown. Funnel plots show the distribution of the percentages meeting the various targets and also whether any of the centres are significantly different from the average.

Longitudinal analysis was performed to show overall changes in achievement of standards from 1998 to 2012.

Erythropoietin data from the last quarter of 2012 were used to define which patients were receiving ESAs. Scotland was excluded from this analysis as data regarding ESA was not included in its return. Each individual was defined as being on ESA if a drug type and/or a dose was present in the data. Centres reporting fewer than $60 \%$ of HD patients or fewer than $45 \%$ of PD patients being treated with ESAs were considered to have incomplete data and were excluded from further analysis. It is recognised that these exclusion criteria are relatively arbitrary but they are in part based upon the frequency distribution graph of centres' ESA use as it appears in the data. The percentage of patients on ESAs is calculated from these data and incomplete data returns risk seriously impacting on any conclusions drawn.

For analyses of ESA dose, values are presented as weekly erythropoietin dose. Doses of less than $150 \mathrm{IU} /$ week (likely to be darbepoietin) were harmonised with erythropoietin data by multiplying by 200 . No adjustments were made with respect to route of 
administration. Patients who were not receiving ESAs were not included in analyses of dose (rather than being included with dose $=0$ ).

Until last year, reports have only used the dose from the final quarter of the year. Now, as last year, starting with the cohort of patients receiving ESAs in the final quarter and having a dose value present for that quarter, any further dose values available from the earlier three quarters of the year were used (provided the patient was on the same treatment and receiving the same drug in those quarters). The average (mean) of the available values was then used in analyses rather than the dose in the final quarter.

The ESA data were collected electronically from renal IT systems but in contrast to laboratory linked variables the ESA data required manual data entry. The reliability depended upon the data source, whether the entry was linked to the prescription or whether the prescriptions were provided by the primary care physician. In the latter case, doses may not be as reliably updated as the link between data entry and prescription is indirect.

\section{Results}

Anaemia management in incident dialysis patients

Haemoglobin in incident dialysis patients

$\mathrm{The} \mathrm{Hb}$ at the time of starting RRT gives the only indication of concordance with current anaemia management recommendations in the pre-dialysis (CKD 5 not yet on dialysis) group.

The percentage of data returned and outcome $\mathrm{Hb}$ are listed in table 10.1. Results are not shown for two centres (Kent and Inverness) because data completeness was less than $50 \%$.

The median $\mathrm{Hb}$ of patients at the time of starting dialysis in the UK was $100 \mathrm{~g} / \mathrm{L}$. The median starting $\mathrm{Hb}$ by centre is shown in figure 10.1. The percentage of patients having a $\mathrm{Hb} 100 \mathrm{~g} / \mathrm{L}$ has fallen over the last couple of years to $51 \%$ from $55 \%$ in the 2009 cohort. The percentage starting with a $\mathrm{Hb} 100 \mathrm{~g} / \mathrm{L}$ by centre is given in figure 10.2.

The variation in the proportion of patients starting renal replacement therapy with $\mathrm{Hb} 100 \mathrm{~g} / \mathrm{L}$ between centres remained high (32-87\%). Using only centres with time of presentation data, the median $\mathrm{Hb}$ in the late presenters was $94 \mathrm{~g} / \mathrm{L}$ with only $34 \%$ of patients having a $\mathrm{Hb} 100 \mathrm{~g} / \mathrm{L}$ compared with a median $\mathrm{Hb}$ of $101 \mathrm{~g} / \mathrm{L}$ and $54 \%$ of the patients having a $\mathrm{Hb} 100 \mathrm{~g} / \mathrm{L}$ in the early presenters group. In the late presenters group there was a large variation between centres in percentage of patients having a $\mathrm{Hb} 100 \mathrm{~g} / \mathrm{L}(9 \%-64 \%)$. The lower median $\mathrm{Hb}$ in late presenters may reflect inadequate pre-dialysis care with limited anaemia management, anaemia of multisystem disease or inter-current illness.
Median $\mathrm{Hb}$ of patients at the time of starting $\mathrm{HD}$ was $97 \mathrm{~g} / \mathrm{L}$ (IQR $89-106 \mathrm{~g} / \mathrm{L}$ ) and in those starting PD was $109 \mathrm{~g} / \mathrm{L}$ (IQR 99-118 g/L). When starting dialysis, 44\% of $\mathrm{HD}$ patients had a $\mathrm{Hb} 100 \mathrm{~g} / \mathrm{L}$, compared with $75 \%$ of PD patients.

Incident dialysis patients from 2011 were followed for one year and the median haemoglobin (and percentage with a $\mathrm{Hb} 100 \mathrm{~g} / \mathrm{L}$ ) of survivors on the same treatment at the same centre after a year was calculated for each quarter. Only patients who had $\mathrm{Hb}$ data for each of the four time points were included in this analysis. This was sub-analysed by modality and length of pre-RRT care (figures 10.3 and 10.4). Hb was higher in the second quarter on dialysis than during the quarter at start of dialysis reflecting the benefits of treatment administered. Over $76 \%$ of incident patients surviving to a year had $\mathrm{Hb}$ $100 \mathrm{~g} / \mathrm{L}$ regardless of the modality or the length of pre-RRT care.

The annual distribution of $\mathrm{Hb}$ in incident dialysis patients is shown in figure 10.5. Since 2006, the proportion of incident patients with $\mathrm{Hb} 120 \mathrm{~g} / \mathrm{L}$ has fallen from $17 \%$ to $10 \%$ and the proportion of patients with $\mathrm{Hb}<100 \mathrm{~g} / \mathrm{L}$ continues to gradually increase over the years from $40 \%$ to $49 \%$. In the 2012 cohort, $66 \%$ of patients in the late presentation group had $\mathrm{Hb}<100 \mathrm{~g} /$ L compared with $46 \%$ in the early presentation group.

\section{ESA by time on dialysis in early vs. late presenters}

Incident dialysis patients from 2011 were followed for one year and the percentages receiving an ESA were calculated for each quarter for survivors on the same treatment at the same centre after a year. This was sub-analysed by modality and length of pre-RRT care (figure 10.6). For HD patients at the start of treatment there was a relatively small difference between early and late presenters in the percentage of patients receiving an ESA. This difference had disappeared within one year of starting dialysis. For PD patients there was a more marked difference between the early and late group which was highest in the second quarter at more than $10 \%$. The difference was lowest 1 year after starting dialysis. Caution is advised in interpreting this figure as the number of patients in the PD late group is relatively small (22).

\section{Anaemia management in prevalent dialysis patients}

Compliance with data returns for haemoglobin and serum ferritin and percentages on ESA are shown for the 71 renal centres in the UK in table 10.2 for both HD and PD patients. Completeness of data returns was 
Table 10.1. Haemoglobin data for incident patients starting haemodialysis or peritoneal dialysis during 2012, both overall and by presentation time

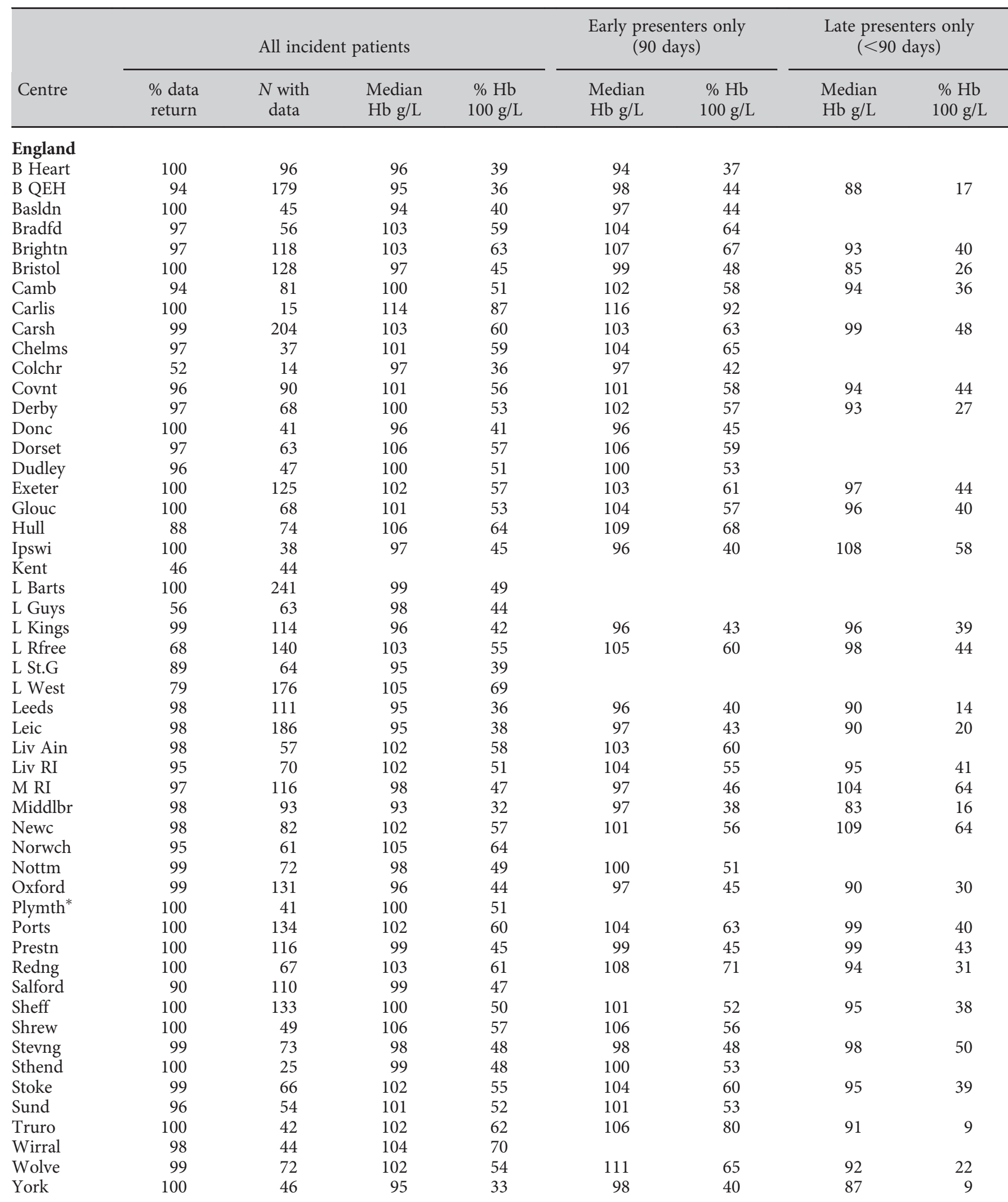


Table 10.1. Continued

\begin{tabular}{|c|c|c|c|c|c|c|c|c|}
\hline \multirow[b]{2}{*}{ Centre } & \multicolumn{4}{|c|}{ All incident patients } & \multicolumn{2}{|c|}{$\begin{array}{l}\text { Early presenters only } \\
\text { (90 days) }\end{array}$} & \multicolumn{2}{|c|}{$\begin{array}{l}\text { Late presenters only } \\
\qquad(<90 \text { days })\end{array}$} \\
\hline & $\begin{array}{l}\% \text { data } \\
\text { return }\end{array}$ & $\begin{array}{l}N \text { with } \\
\text { data }\end{array}$ & $\begin{array}{l}\text { Median } \\
\mathrm{Hb} \text { g/L }\end{array}$ & $\begin{array}{c}\% \mathrm{Hb} \\
100 \mathrm{~g} / \mathrm{L}\end{array}$ & $\begin{array}{l}\text { Median } \\
\mathrm{Hb} \text { g/L }\end{array}$ & $\begin{array}{c}\% \mathrm{Hb} \\
100 \mathrm{~g} / \mathrm{L}\end{array}$ & $\begin{array}{l}\text { Median } \\
\mathrm{Hb} \mathrm{g} / \mathrm{L}\end{array}$ & $\begin{array}{c}\% \mathrm{Hb} \\
100 \mathrm{~g} / \mathrm{L}\end{array}$ \\
\hline \multicolumn{9}{|l|}{ N Ireland } \\
\hline Antrim & 100 & 26 & 102 & 54 & 104 & 58 & & \\
\hline Ulster & 100 & 21 & 109 & 71 & 109 & 76 & & \\
\hline West NI & 89 & 16 & 98 & 38 & 98 & 36 & & \\
\hline \multicolumn{9}{|l|}{ Scotland } \\
\hline Abrdn & 100 & 54 & 98 & 46 & & & & \\
\hline Airdrie & 68 & 40 & 95 & 40 & & & & \\
\hline D \& Gall & 65 & 11 & 99 & 45 & & & & \\
\hline Glasgw & 64 & 103 & 98 & 47 & & & & \\
\hline Inverns & 46 & 6 & & & & & & \\
\hline Klmarnk & 78 & 29 & 94 & 45 & & & & \\
\hline \multicolumn{9}{|l|}{ Wales } \\
\hline Bangor & 95 & 18 & 102 & 67 & 101 & 64 & & \\
\hline Cardff & 100 & 137 & 103 & 61 & 104 & 65 & 94 & 29 \\
\hline Clwyd & 100 & 19 & 103 & 63 & 103 & 67 & & \\
\hline Swanse & 99 & 97 & 99 & 46 & 103 & 58 & 89 & 16 \\
\hline Wrexm & 97 & 30 & 108 & 67 & 109 & 71 & & \\
\hline England & 93 & 4,480 & 100 & 51 & 101 & 53 & 94 & 34 \\
\hline N Ireland & 97 & 138 & 103 & 57 & 104 & 59 & 95 & 38 \\
\hline Scotland & 75 & 349 & 99 & 48 & & & & \\
\hline
\end{tabular}

Blank cells denote centres excluded from analyses due to poor data completeness or low patient numbers or because presentation time data not available

*Plymouth, approximately $33 \%$ of incident patients were missing from the data extract

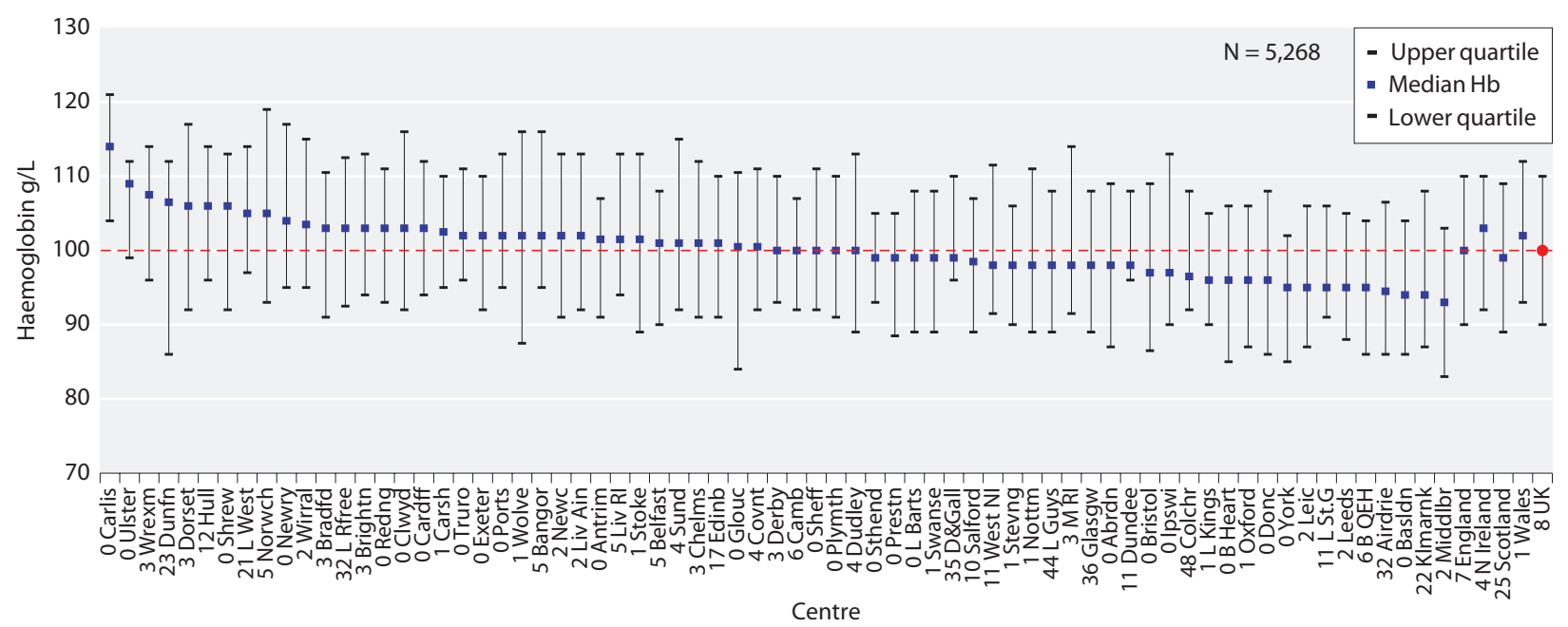

Fig. 10.1. Median haemoglobin for incident dialysis patients at start of dialysis treatment in 2012 


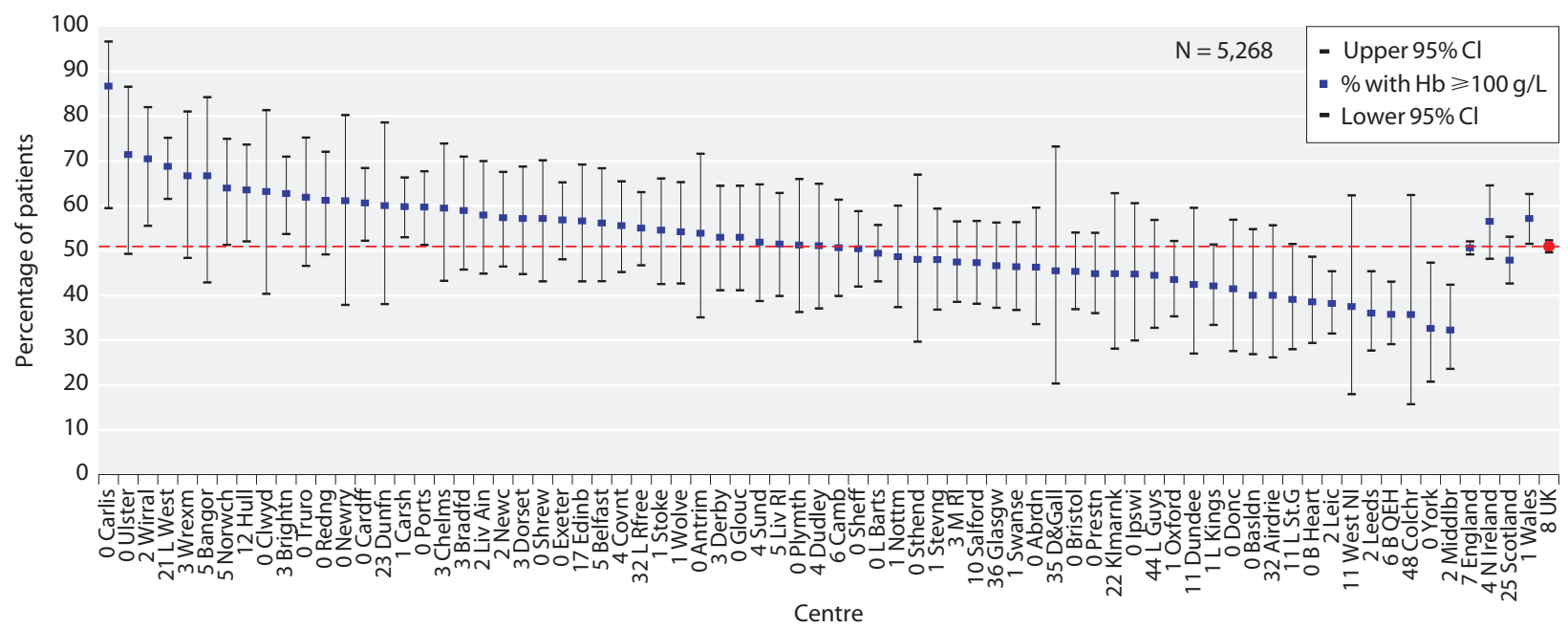

Fig. 10.2. Percentage of incident dialysis patients with $\mathrm{Hb} 100 \mathrm{~g} / \mathrm{L}$ at start of dialysis treatment in 2012

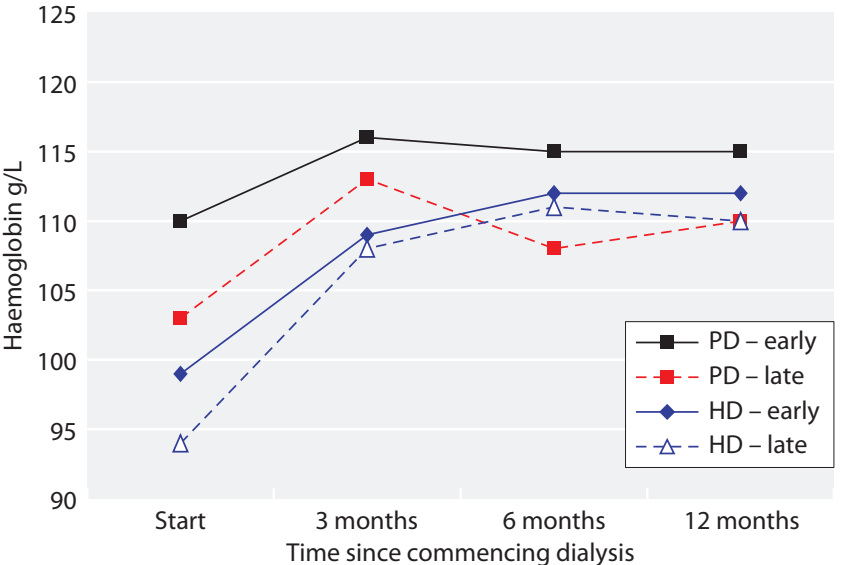

Fig. 10.3. Median haemoglobin, by time on dialysis and length of pre-RRT care, for incident dialysis patients in 2011

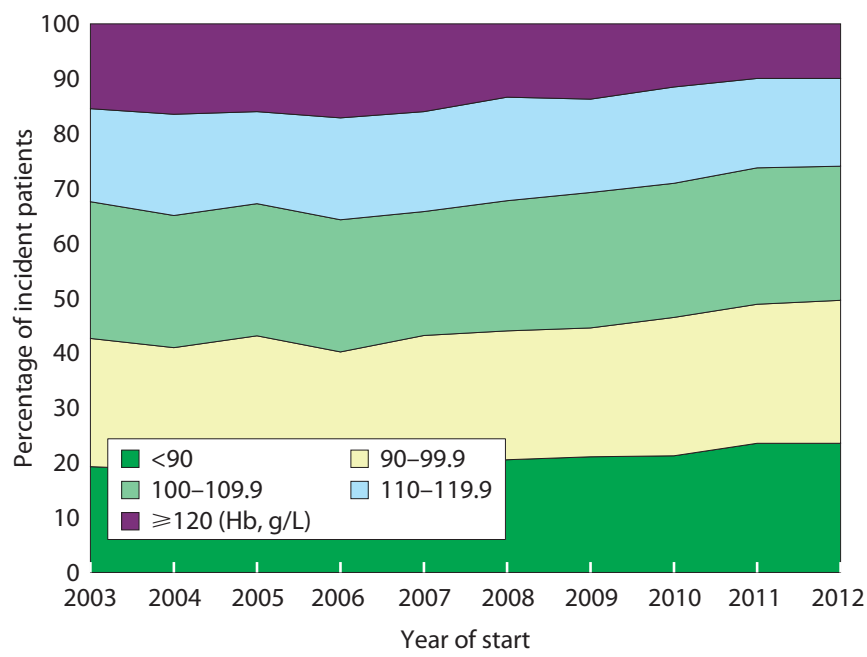

Fig. 10.5. Distribution of haemoglobin in incident dialysis patients by year of start

Anaemia management in UK dialysis patients

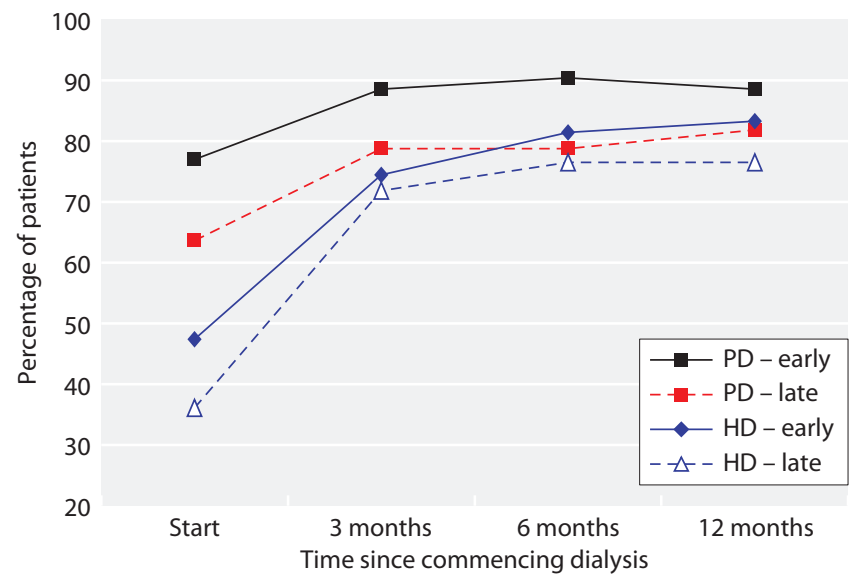

Fig. 10.4. Percentage of incident dialysis patients in 2011 with $\mathrm{Hb}$ $100 \mathrm{~g} / \mathrm{L}$, by time on dialysis and by length of pre-RRT care

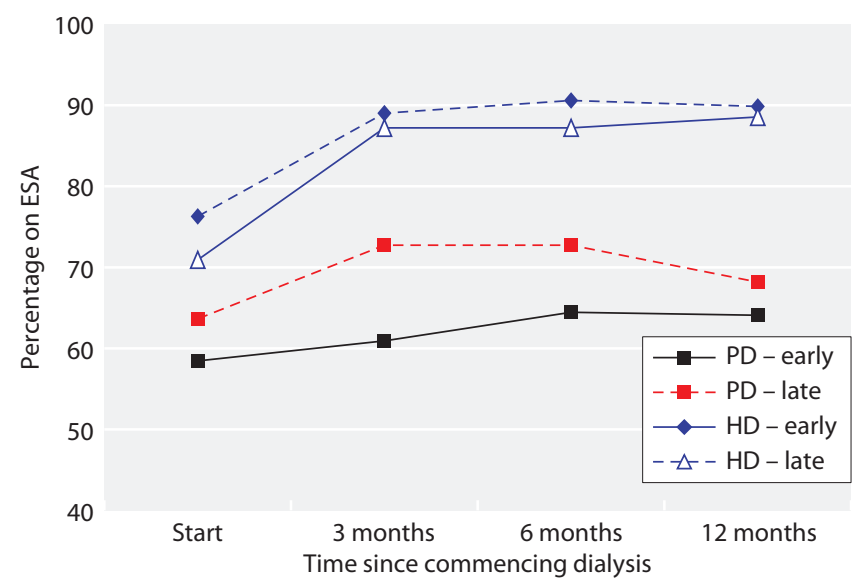

Fig. 10.6. Percentage of incident dialysis patients in 2011 on ESA, by time on dialysis and by length of pre-RRT care 
Table 10.2. Percentage completeness of data returns for haemoglobin and serum ferritin and percentages on ESA for prevalent HD and PD patients in 2012

\begin{tabular}{|c|c|c|c|c|c|c|c|c|}
\hline \multirow[b]{2}{*}{ Centre } & \multicolumn{4}{|c|}{ HD } & \multicolumn{4}{|c|}{ PD } \\
\hline & $N$ & $\mathrm{Hb}$ & Ferritin & $\%$ on ESA & $N$ & $\mathrm{Hb}$ & Ferritin & $\%$ on ESA \\
\hline B Heart & 401 & 100 & 100 & 77 & 42 & 100 & 98 & 48 \\
\hline B QEH & 864 & 97 & 96 & 84 & 149 & 99 & 97 & 62 \\
\hline Basldn & 150 & 98 & 97 & 91 & 28 & 100 & 100 & 61 \\
\hline Brightn & 338 & 96 & 86 & 0 & 69 & 94 & 83 & 0 \\
\hline Bristol & 461 & 100 & 100 & 92 & 56 & 100 & 100 & 66 \\
\hline Camb & 324 & 95 & 76 & 43 & 32 & 100 & 97 & 59 \\
\hline Carlis & 57 & 100 & 70 & 68 & 21 & 100 & 95 & 67 \\
\hline Carsh & 698 & 95 & 92 & 0 & 97 & 98 & 99 & 0 \\
\hline Chelms & 121 & 100 & 99 & 97 & 25 & 100 & 100 & 76 \\
\hline Dorset & 244 & 100 & 98 & 97 & 38 & 95 & 87 & 68 \\
\hline Dudley & 153 & 100 & 99 & 3 & 53 & 100 & 89 & 4 \\
\hline Exeter & 351 & 100 & 100 & 93 & 69 & 100 & 100 & 72 \\
\hline Glouc & 193 & 100 & 98 & 91 & 31 & 100 & 77 & 55 \\
\hline Hull & 310 & 100 & 99 & 0 & 79 & 97 & 95 & 0 \\
\hline Ipswi & 124 & 100 & 99 & 65 & 30 & 100 & 90 & 70 \\
\hline Kent & 361 & 100 & 99 & 91 & 55 & 100 & 96 & 67 \\
\hline L Barts & 846 & 100 & 99 & 0 & 167 & 99 & 95 & 0 \\
\hline L Guys & 592 & 91 & 81 & 19 & 27 & 96 & 96 & 7 \\
\hline L Kings & 460 & 100 & 97 & 0 & 76 & 100 & 99 & 0 \\
\hline L Rfree & 668 & 86 & 81 & 0 & 102 & 99 & 86 & 0 \\
\hline Middlbr & 312 & 98 & 98 & 78 & 8 & 88 & 88 & 75 \\
\hline Newc & 262 & 100 & 100 & 69 & 37 & 86 & 92 & 0 \\
\hline Norwch & 303 & 100 & 98 & 91 & 48 & 100 & 98 & 71 \\
\hline Nottm & 355 & 100 & 100 & 90 & 72 & 100 & 100 & 69 \\
\hline Oxford & 389 & 100 & 100 & 93 & 69 & 100 & 99 & 81 \\
\hline Plymth & 119 & 100 & 98 & 0 & 31 & 97 & 77 & 0 \\
\hline Ports & 510 & 100 & 99 & 10 & 78 & 100 & 100 & 12 \\
\hline Prestn & 496 & 100 & 99 & 88 & 59 & 100 & 100 & 75 \\
\hline Redng & 251 & 100 & 100 & 90 & 63 & 100 & 98 & 2 \\
\hline Salford & 345 & 88 & 0 & 68 & 90 & 93 & 0 & 77 \\
\hline Sheff & 562 & 100 & 100 & 86 & 67 & 100 & 100 & 60 \\
\hline Shrew & 184 & 100 & 99 & 88 & 33 & 97 & 94 & 61 \\
\hline Stevng & 380 & 99 & 99 & 0 & 27 & 100 & 89 & 0 \\
\hline Sthend & 107 & 100 & 100 & 97 & 14 & 100 & 100 & 57 \\
\hline Stoke & 294 & 86 & 99 & 1 & 69 & 100 & 99 & 0 \\
\hline Sund & 184 & 99 & 93 & 95 & 17 & 100 & 94 & 65 \\
\hline Truro & 134 & 99 & 99 & 0 & 19 & 100 & 89 & 0 \\
\hline Wirral & 177 & 98 & 97 & 0 & 29 & 79 & 62 & 0 \\
\hline
\end{tabular}


Table 10.2. Continued

\begin{tabular}{|c|c|c|c|c|c|c|c|c|}
\hline \multirow[b]{2}{*}{ Centre } & \multicolumn{4}{|c|}{ HD } & \multicolumn{4}{|c|}{ PD } \\
\hline & $N$ & $\mathrm{Hb}$ & Ferritin & $\%$ on ESA & $N$ & $\mathrm{Hb}$ & Ferritin & $\%$ on ESA \\
\hline Wolve & 270 & 100 & 99 & 85 & 83 & 100 & 100 & 63 \\
\hline York & 122 & 100 & 100 & 93 & 27 & 100 & 96 & 70 \\
\hline \multicolumn{9}{|l|}{$\mathrm{N}$ Ireland } \\
\hline Antrim & 126 & 100 & 100 & 92 & 10 & 100 & 100 & 80 \\
\hline Belfast & 208 & 99 & 97 & 90 & 25 & 100 & 96 & 80 \\
\hline Newry & 85 & 99 & 28 & 95 & 14 & 100 & 100 & 86 \\
\hline Ulster & 101 & 100 & 100 & 93 & 6 & 100 & 100 & 100 \\
\hline West NI & 129 & 98 & 59 & 92 & 15 & 100 & 100 & 67 \\
\hline \multicolumn{9}{|l|}{ Scotland } \\
\hline Abrdn & 214 & 100 & 93 & & 20 & 100 & & \\
\hline Airdrie & 176 & 100 & 97 & & 10 & 100 & & \\
\hline D \& Gall & 48 & 100 & 98 & & 14 & 93 & & \\
\hline Dundee & 171 & 99 & 88 & & 19 & 95 & & \\
\hline Dunfn & 140 & 100 & 89 & & 20 & 95 & & \\
\hline Edinb & 250 & 100 & 93 & & 35 & 100 & & \\
\hline Glasgw & 579 & 99 & 72 & & 40 & 100 & & \\
\hline Inverns & 73 & 100 & 64 & & 15 & 93 & & \\
\hline Klmarnk & 141 & 100 & 91 & & 40 & 100 & & \\
\hline \multicolumn{9}{|l|}{ Wales } \\
\hline Bangor & 82 & 100 & 100 & 79 & 14 & 100 & 100 & 50 \\
\hline Cardff & 448 & 100 & 99 & 61 & 71 & 100 & 73 & 27 \\
\hline Clwyd & 76 & 100 & 100 & 0 & 15 & 100 & 93 & 0 \\
\hline Swanse & 308 & 100 & 100 & 92 & 54 & 100 & 89 & 78 \\
\hline Wrexm & 86 & 100 & 73 & 91 & 20 & 100 & 45 & 55 \\
\hline England & 18,324 & 98 & 95 & 88 & 2,864 & 98 & 92 & 69 \\
\hline N Ireland & 649 & 99 & 82 & 92 & 70 & 100 & 99 & 80 \\
\hline Scotland & 1,792 & 100 & 85 & & 213 & 98 & & \\
\hline Wales & 1,000 & 100 & 97 & 76 & 174 & 100 & 79 & 68 \\
\hline UK & 21,765 & 98 & 93 & $87^{*}$ & 3,321 & 99 & $94^{*}$ & $69^{*}$ \\
\hline
\end{tabular}

*The overall averages given are for $\mathrm{E}, \mathrm{W} \& \mathrm{NI}$ (not UK)

Blank cells denote centres with no PD patients or because data was not available

Percentages on ESA are shown, but it is believed that there were data problems for those centres with apparently less than $60 \%$ of HD patients or $45 \%$ of PD patients on ESA

The country level averages for the \% on ESA are based only on those centres whose \% was above the limits mentioned above

generally good for $\mathrm{Hb}$ and ferritin. The percentages on ESA are shown as they appear in the data received by the registry. For some centres, the ESA data was completely missing and for others it appears to be partially complete with, for example, only 10 or $20 \%$ of patients appearing to be on ESAs. It is believed that there were problems with data entry and/or data transfer in those centres with apparently less than $60 \%$ of HD patients or $45 \%$ of PD patients on ESA. These centres have been excluded from further analyses of ESA use.

Summary statistics for haemoglobin, serum ferritin and ESA are shown for the 71 renal centres in the UK in tables 10.3 for $\mathrm{HD}$ and 10.4 for PD patients respectively.

\section{Haemoglobin in prevalent haemodialysis patients}

The median $\mathrm{Hb}$ of patients on $\mathrm{HD}$ in the UK was $112 \mathrm{~g} / \mathrm{L}$ with an IQR of $103-121 \mathrm{~g} / \mathrm{L}$ and $82 \%$ of HD patients had a $\mathrm{Hb} 100 \mathrm{~g} / \mathrm{L}$ (table 10.3). The median $\mathrm{Hb}$ by centre is shown in figure 10.7. Compliance with the target range of $\mathrm{Hb} 100$ and $120 \mathrm{~g} / \mathrm{L}$ continues to increase year on year, $52.7 \%$ in $2010,56.1 \%$ in 2011 and $57 \%$ in 2012 (figure 10.8). The percentages of HD patients with $\mathrm{Hb}$ below $100 \mathrm{~g} / \mathrm{L}$ and above $120 \mathrm{~g} / \mathrm{L}$, as well as the percentages meeting the target, are shown by centre in figure 10.9.

Funnel plots are shown for the minimum ( $\mathrm{Hb} 100 \mathrm{~g} / \mathrm{L}$ ) and target range $(\mathrm{Hb} 100$ and $120 \mathrm{~g} / \mathrm{L})$ in figures 10.10 and 10.11 respectively. Many centres complied well 
Table 10.3. Summary statistics for haemoglobin, serum ferritin and ESA for prevalent HD patients in 2012

\begin{tabular}{|c|c|c|c|c|c|c|c|c|c|c|}
\hline Centre & $\begin{array}{l}N \text { with } \\
\mathrm{Hb} \text { data }\end{array}$ & $\begin{array}{l}\text { Median } \\
\mathrm{Hb} \text { g/L }\end{array}$ & $\begin{array}{c}\% \mathrm{Hb} \\
100 \mathrm{~g} / \mathrm{L}\end{array}$ & $\begin{array}{c}\% \mathrm{Hb} \\
100- \\
120 \mathrm{~g} / \mathrm{L}\end{array}$ & $\begin{array}{c}\text { Median } \\
\text { ferritin } \\
\mu \mathrm{g} / \mathrm{L}\end{array}$ & $\begin{array}{c}\% \\
\text { ferritin } \\
100 \mu \mathrm{g} / \mathrm{L}\end{array}$ & $\begin{array}{l}\% \text { ferritin } \\
>200 \text { and } \\
500 \mu \mathrm{g} / \mathrm{L}\end{array}$ & $\begin{array}{l}\% \text { on } \\
\text { ESA }\end{array}$ & $\begin{array}{l}\text { Median } \\
\text { ESA dose } \\
\text { (IU/week) }\end{array}$ & $\begin{array}{l}\text { \% with } \mathrm{Hb} \\
100 \mathrm{~g} / \mathrm{L} \text { and not } \\
\text { on ESA }\end{array}$ \\
\hline B Heart & 401 & 108 & 70 & 52 & 333 & 94 & 57 & 77 & 6,667 & 21 \\
\hline B QEH & 838 & 111 & 82 & 59 & 354 & 95 & 77 & 84 & 7,000 & 14 \\
\hline Basldn & 147 & 108 & 67 & 47 & 339 & 93 & 72 & 91 & 6,000 & 6 \\
\hline Bristol & 461 & 113 & 85 & 57 & 564 & 96 & 31 & 92 & 7,500 & 8 \\
\hline Camb & 309 & 113 & 85 & 59 & 306 & 88 & 56 & & & \\
\hline Carlis & 57 & 115 & 84 & 42 & 439 & 93 & 50 & 68 & 4,750 & 32 \\
\hline Carsh & 660 & 111 & 84 & 70 & 375 & 95 & 63 & & & \\
\hline Chelms & 121 & 118 & 93 & 50 & 631 & 100 & 22 & 97 & 10,000 & 3 \\
\hline Dorset & 244 & 115 & 85 & 52 & 453 & 97 & 51 & 97 & 9,250 & 3 \\
\hline Dudley & 153 & 111 & 76 & 50 & 333 & 95 & 70 & & & \\
\hline Exeter & 351 & 112 & 83 & 62 & 265 & 90 & 62 & 93 & 7,500 & 6 \\
\hline Glouc & 193 & 111 & 83 & 63 & 330 & 89 & 49 & 91 & & 8 \\
\hline Hull & 309 & 116 & 88 & 51 & 393 & 99 & 64 & & & \\
\hline Ipswi & 124 & 111 & 80 & 55 & 611 & 98 & 28 & 65 & 7,500 & 29 \\
\hline Kent & 361 & 113 & 86 & 59 & 445 & 93 & 38 & 91 & 8,250 & 7 \\
\hline L Barts & 844 & 109 & 76 & 61 & 432 & 95 & 53 & & & \\
\hline L Guys & 537 & 107 & 71 & 55 & 693 & 97 & 26 & & & \\
\hline L Kings & 460 & 107 & 73 & 61 & 579 & 98 & 35 & & & \\
\hline L Rfree & 576 & 112 & 84 & 58 & 425 & 91 & 41 & & & \\
\hline L St.G & 263 & 111 & 80 & 59 & 458 & 97 & 47 & & & \\
\hline Newc & 262 & 116 & 84 & 50 & 424 & 95 & 43 & 69 & 11,025 & 28 \\
\hline Norwch & 302 & 115 & 87 & 59 & 444 & 93 & 35 & 91 & 8,000 & 9 \\
\hline Nottm & 354 & 113 & 84 & 62 & 582 & 99 & 24 & 90 & 7,500 & 10 \\
\hline Oxford & 389 & 112 & 81 & 55 & 308 & 94 & 57 & 93 & 8,000 & 6 \\
\hline Plymth & 119 & 112 & 83 & 60 & 752 & 97 & 22 & & & \\
\hline Ports & 509 & 117 & 89 & 49 & 357 & 97 & 67 & & & \\
\hline Prestn & 494 & 113 & 83 & 58 & 577 & 94 & 30 & 88 & & 11 \\
\hline Redng & 251 & 116 & 84 & 56 & 536 & 98 & 38 & 90 & & 8 \\
\hline Salford & 303 & 108 & 73 & 58 & & & & 68 & 6,000 & 14 \\
\hline Sheff & 562 & 112 & 79 & 54 & 488 & 96 & 45 & 86 & 7,500 & 11 \\
\hline Shrew & 184 & 115 & 89 & 55 & 391 & 98 & 57 & 88 & & 11 \\
\hline Stevng & 376 & 114 & 86 & 60 & 521 & 97 & 37 & & & \\
\hline Sthend & 107 & 111 & 82 & 66 & 313 & 98 & 72 & 97 & 9,000 & 3 \\
\hline Stoke & 254 & 115 & 84 & 54 & 405 & 97 & 49 & & & \\
\hline Sund & 183 & 111 & 81 & 56 & 615 & 95 & 26 & 95 & & 5 \\
\hline Truro & 133 & 111 & 83 & 66 & 460 & 97 & 52 & & & \\
\hline Wirral & 173 & 112 & 82 & 62 & 537 & 98 & 35 & & & \\
\hline Wolve & 269 & 115 & 86 & 53 & 473 & 96 & 44 & 85 & 6,750 & 14 \\
\hline York & 122 & 110 & 75 & 57 & 414 & 97 & 69 & 93 & 4,000 & 6 \\
\hline
\end{tabular}


Table 10.3. Continued

\begin{tabular}{|c|c|c|c|c|c|c|c|c|c|c|}
\hline Centre & $\begin{array}{l}N \text { with } \\
\mathrm{Hb} \text { data }\end{array}$ & $\begin{array}{l}\text { Median } \\
\mathrm{Hb} \text { g/L }\end{array}$ & $\begin{array}{c}\% \mathrm{Hb} \\
100 \mathrm{~g} / \mathrm{L}\end{array}$ & $\begin{array}{c}\% \mathrm{Hb} \\
100- \\
120 \mathrm{~g} / \mathrm{L}\end{array}$ & $\begin{array}{l}\text { Median } \\
\text { ferritin } \\
\mu \mathrm{g} / \mathrm{L}\end{array}$ & $\begin{array}{c}\% \\
\text { ferritin } \\
100 \mu \mathrm{g} / \mathrm{L}\end{array}$ & $\begin{array}{l}\% \text { ferritin } \\
>200 \text { and } \\
500 \mu \mathrm{g} / \mathrm{L}\end{array}$ & $\begin{array}{l}\% \text { on } \\
\text { ESA }\end{array}$ & $\begin{array}{l}\text { Median } \\
\text { ESA dose } \\
\text { (IU/week) }\end{array}$ & $\begin{array}{c}\% \text { with } \mathrm{Hb} \\
100 \mathrm{~g} / \mathrm{L} \text { and not } \\
\text { on ESA }\end{array}$ \\
\hline \multicolumn{11}{|l|}{ N Ireland } \\
\hline Antrim & 126 & 115 & 88 & 60 & 469 & 98 & 52 & 92 & 6,000 & 7 \\
\hline Belfast & 205 & 111 & 78 & 57 & 434 & 95 & 41 & 90 & 8,000 & 7 \\
\hline Newry & 84 & 112 & 86 & 62 & & & & 95 & 4,300 & 5 \\
\hline \multicolumn{11}{|l|}{ Scotland } \\
\hline Abrdn & 213 & 108 & 69 & 50 & 634 & 99 & 32 & & & \\
\hline Airdrie & 176 & 113 & 86 & 62 & 669 & 99 & 30 & & & \\
\hline D \& Gall & 48 & 108 & 85 & 67 & 648 & 96 & 23 & & & \\
\hline Dundee & 170 & 113 & 82 & 64 & 289 & 84 & 47 & & & \\
\hline Klmarnk & 141 & 113 & 82 & 52 & 332 & 91 & 54 & & & \\
\hline \multicolumn{11}{|l|}{ Wales } \\
\hline Bangor & 82 & 116 & 89 & 59 & 432 & 96 & 54 & 79 & 9,000 & 17 \\
\hline Cardff & 447 & 112 & 83 & 58 & 301 & 94 & 64 & 61 & & 33 \\
\hline Clwyd & 76 & 113 & 89 & 61 & 358 & 100 & 68 & & & \\
\hline Swanse & 308 & 112 & 85 & 66 & 386 & 94 & 45 & 91 & 7,500 & 8 \\
\hline Wrexm & 86 & 113 & 87 & 58 & 485 & 97 & 43 & 92 & 5,000 & 8 \\
\hline England & 17,885 & 112 & 82 & 57 & 432 & 96 & 48 & 88 & 7,333 & 10 \\
\hline N Ireland & 642 & 112 & 82 & 60 & 535 & 96 & 35 & 92 & 6,500 & 7 \\
\hline Scotland & 1,783 & 114 & 85 & 54 & 448 & 94 & 40 & & & \\
\hline Wales & 999 & 113 & 85 & 60 & 348 & 95 & 56 & 76 & 7,500 & 21 \\
\hline
\end{tabular}

Blank cells denote centres excluded from analyses due to poor data completeness or low patient numbers or because the data item was not available ESA data only shown for those centres for which the $\%$ on ESA was $60 \%$ or more

For ESA, the overall averages given are for $\mathrm{E}, \mathrm{W} \& \mathrm{NI}$ not UK

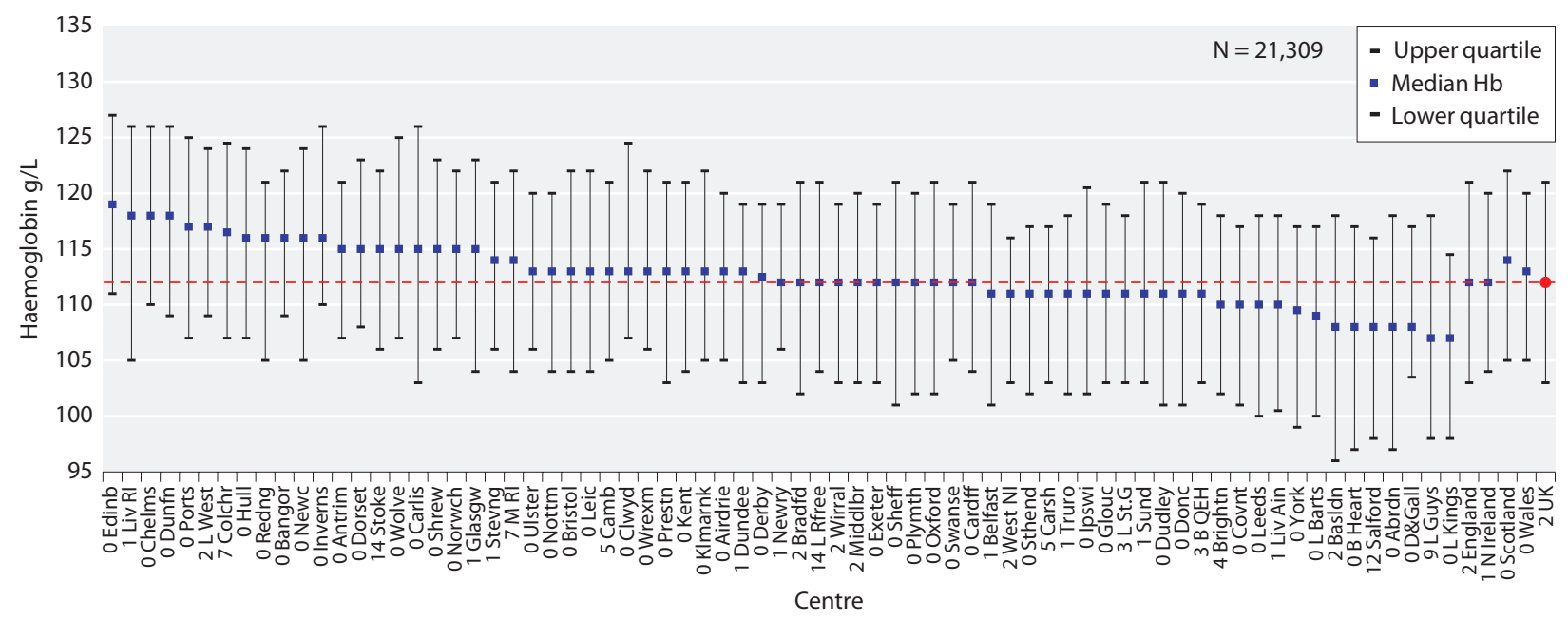

Fig. 10.7. Median haemoglobin in patients treated with HD by centre in 2012 


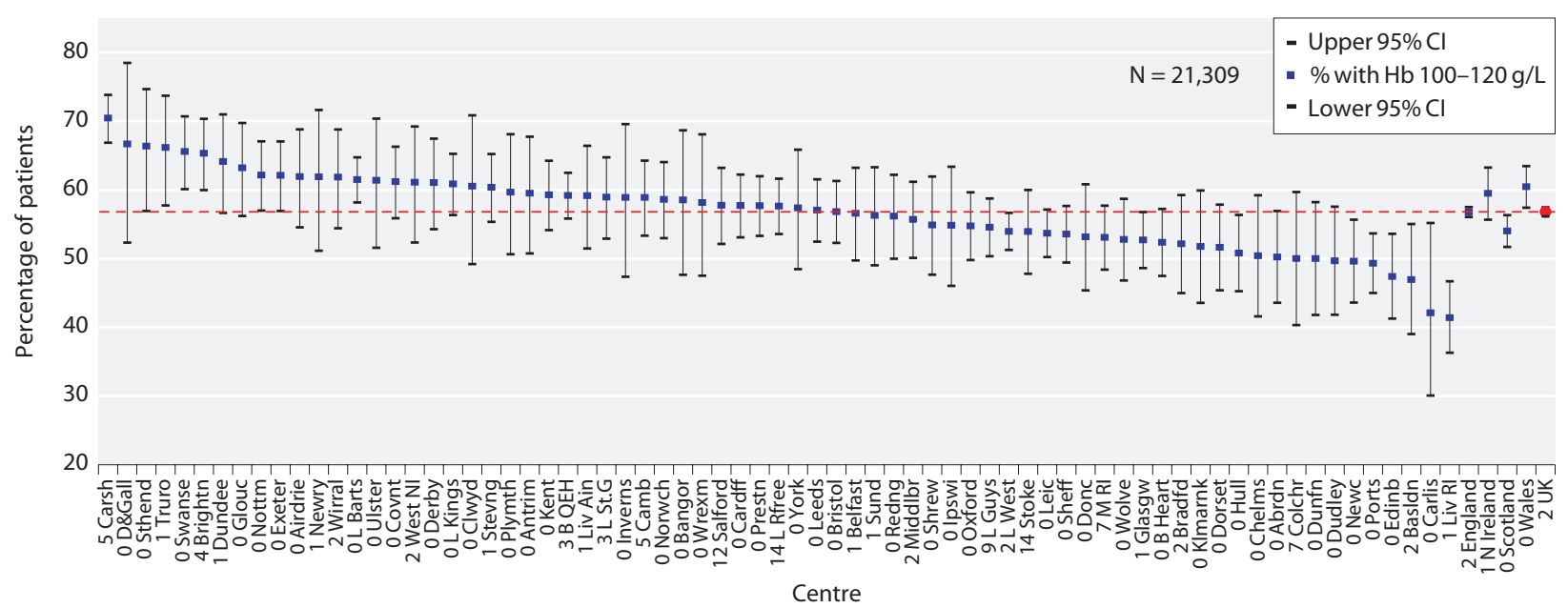

Fig. 10.8. Percentage of HD patients with $\mathrm{Hb} 100$ and $120 \mathrm{~g} / \mathrm{L}$ by centre in 2012

with respect to both the minimum and target range $\mathrm{Hb}$ standards. Some centres complied well with the percentage with $\mathrm{Hb} 100 \mathrm{~g} / \mathrm{L}$ (figure 10.10) but had a poor compliance with percentage of patients with $\mathrm{Hb} 100$ and $120 \mathrm{~g} / \mathrm{L}$ (figure 10.11). This demonstrates that compliance with one standard can be achieved without compliance with another standard. Table 10.3 can be used in conjunction with figures 10.10 and 10.11 to identify centres.

\section{Haemoglobin in prevalent peritoneal dialysis patients}

Overall, $85 \%$ of patients on PD had a $\mathrm{Hb} 100 \mathrm{~g} / \mathrm{L}$ (table 10.4). The median $\mathrm{Hb}$ of patients on $\mathrm{PD}$ in the UK in 2012 was $114 \mathrm{~g} / \mathrm{L}$ with an IQR of $105-123 \mathrm{~g} / \mathrm{L}$. The median $\mathrm{Hb}$ by centre is shown in figure 10.12 . The compliance with $\mathrm{Hb} 100$ and $120 \mathrm{~g} / \mathrm{L}$ is shown in figure 10.13. In 2012, 55\% of prevalent PD patients had a $\mathrm{Hb}$ within the target range. The distribution of $\mathrm{Hb}$ in $\mathrm{PD}$ patients by centre is shown in figure 10.14. The funnel plots for percentage with $\mathrm{Hb} 100 \mathrm{~g} / \mathrm{L}$ and for the percentage of patients with $\mathrm{Hb} 100$ and $120 \mathrm{~g} / \mathrm{L}$ are shown in figures 10.15 and 10.16 respectively. Table 10.4 can be used in conjunction with figures 10.15 and 10.16 to identify centres in the funnel plot.

Relationship between $\mathrm{Hb}$ in incident and prevalent dialysis patients in 2012

The relationship between the percentage of incident and prevalent dialysis (HD and $\mathrm{PD}$ ) patients with a $\mathrm{Hb}$ $100 \mathrm{~g} / \mathrm{L}$ is shown in figure 10.17. As expected, all centres

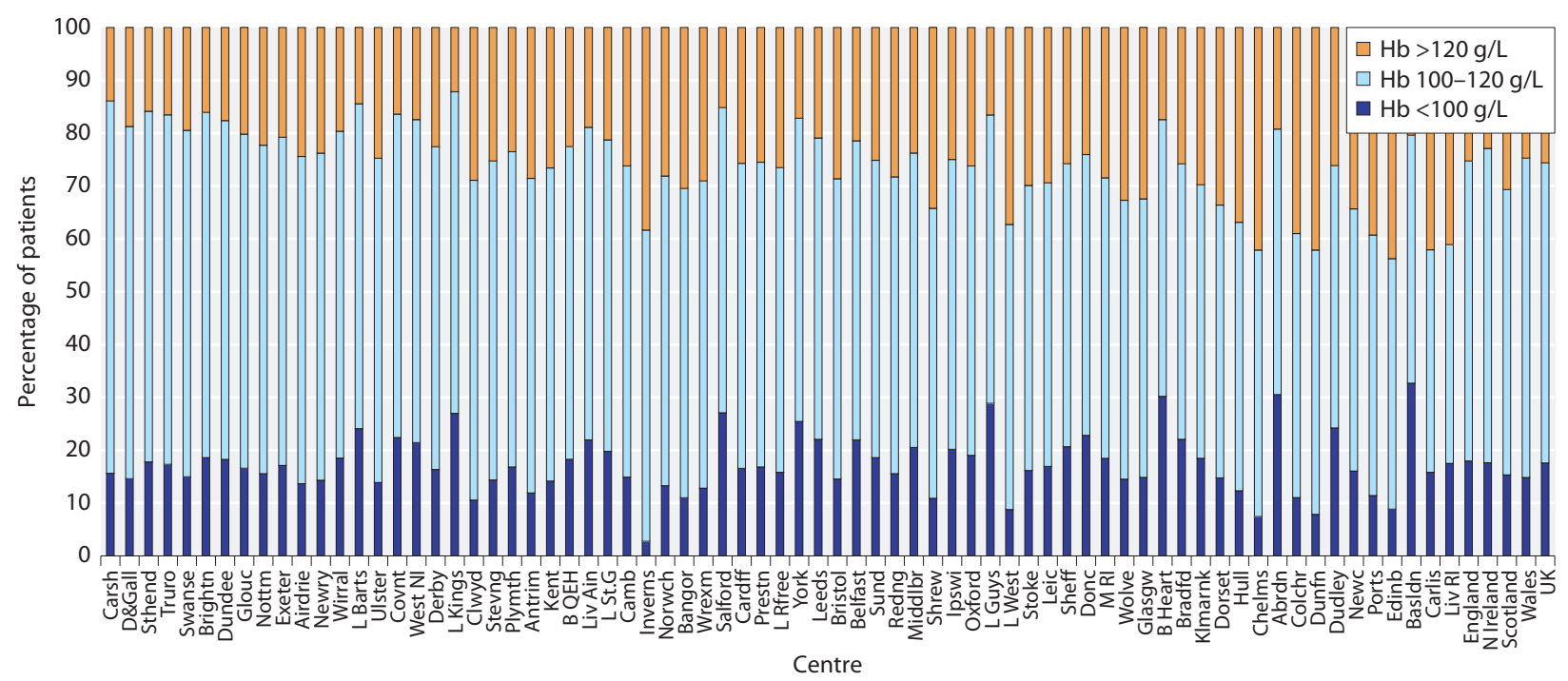

Fig. 10.9. Distribution of haemoglobin in patients treated with HD by centre in 2012 


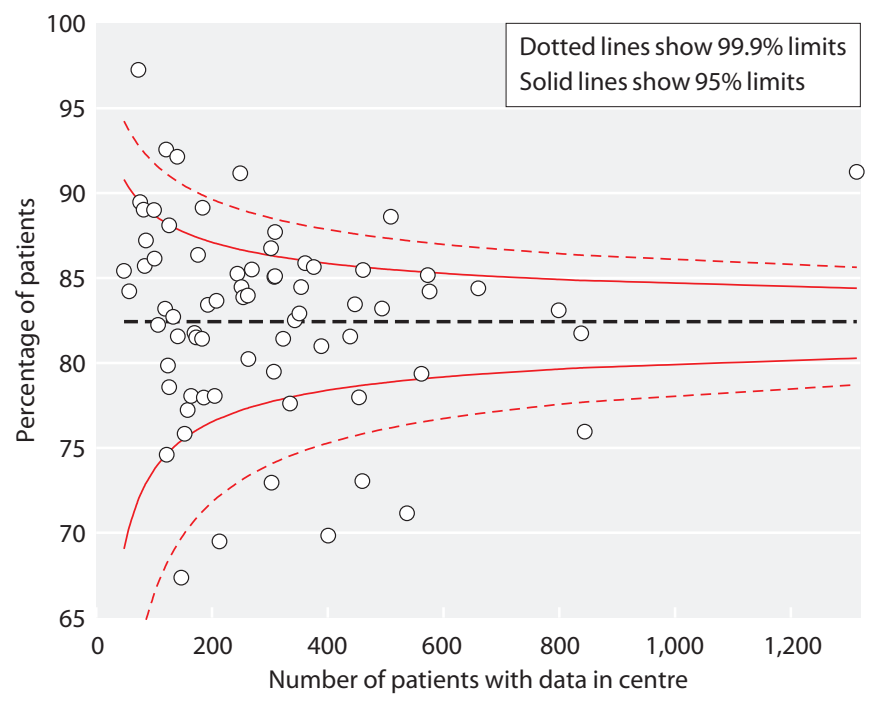

Fig. 10.10. Funnel plot of percentage of $\mathrm{HD}$ patients with $\mathrm{Hb}$ $100 \mathrm{~g} / \mathrm{L}$ by centre in 2012

had a higher percentage of prevalent patients achieving a $\mathrm{Hb} 100 \mathrm{~g} / \mathrm{L}$ than that for incident patients. Overall in the UK, $83 \%$ of prevalent patients, compared with $51 \%$ of incident patients, had a $\mathrm{Hb} 100 \mathrm{~g} / \mathrm{L}$ in 2012. Compliance with 'current' minimum standards by year (1998-2012) for incident and prevalent patients (all dialysis patients) is shown in figure 10.18. The decline in achieving this standard for incident and prevalent patients continues.

\section{Ferritin in prevalent haemodialysis patients}

The median and IQR for serum ferritin for patients treated with HD are shown in figure 10.19. The percentages with serum ferritin $100 \mu \mathrm{g} / \mathrm{L},>200 \mu \mathrm{g} / \mathrm{L}$ and

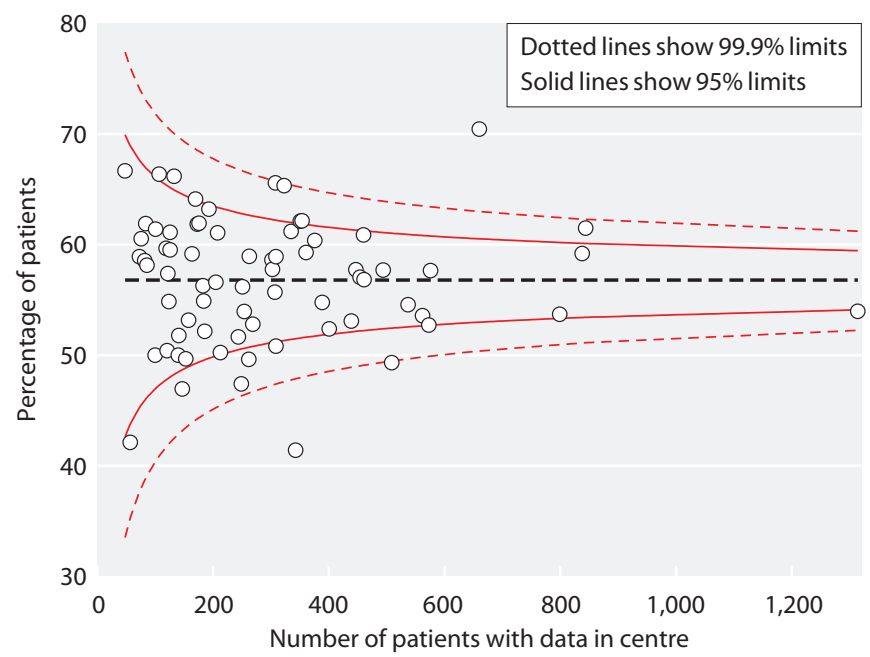

Fig. 10.11. Funnel plot of percentage of $\mathrm{HD}$ patients with $\mathrm{Hb} 100$ and $120 \mathrm{~g} / \mathrm{L}$ by centre in 2012
$500 \mu \mathrm{g} / \mathrm{L}$, and $800 \mu \mathrm{g} / \mathrm{L}$ are shown in figures 10.20 , 10.21 and 10.22 respectively. Most centres achieved greater than $90 \%$ compliance with a serum ferritin $100 \mu \mathrm{g} / \mathrm{L}$ for HD patients. The HD population had a median ferritin value of $431 \mu \mathrm{g} / \mathrm{L}$, IQR 285-623. Seventeen of the 69 centres who had returns for ferritin had greater than $20 \%(21-47 \%)$ of their patients with ferritin $800 \mu \mathrm{g} / \mathrm{L}$ (figure 10.22). The serum ferritin correlated poorly with median $\mathrm{Hb}$ achieved and ESA dose (table 10.3).

\section{Ferritin in prevalent peritoneal dialysis patients}

The median and IQR for serum ferritin for patients treated with PD are shown in figure 10.23. The percentages with serum ferritin $100 \mu \mathrm{g} / \mathrm{L},>100 \mu \mathrm{g} / \mathrm{L}$ and $500 \mu \mathrm{g} / \mathrm{L}$, and $800 \mu \mathrm{g} / \mathrm{L}$ are shown in figures 10.24 , 10.25 and 10.26 respectively. The PD population had a lower median ferritin value (285 $\mu \mathrm{g} / \mathrm{L}$, IQR $164-466)$ than the HD population. In 2012, 31 centres reported less than $90 \%$ of PD patients compliant with serum ferritin $100 \mu \mathrm{g} / \mathrm{L}$, although this had little bearing on their achieved median $\mathrm{Hb}$ or median ESA dose when compared with other centres (table 10.4).

\section{Erythropoietin stimulating agents in prevalent haemodialysis patients}

As shown in previous reports there was substantial variation in the average dose of ESA prescription used. The median dose for prevalent HD patients in England, Wales and Northern Ireland was 7,248 IU/week. The median dose varied from 4,000 IU/week (Leeds, York) to $11,025 \mathrm{IU} /$ week (Newcastle) with a median $\mathrm{Hb}$ for these centres of $110 \mathrm{~g} / \mathrm{L}$ (Leeds, York) and $116 \mathrm{~g} / \mathrm{L}$ (Newcastle) (table 10.3). Over the last three years there has been a fall in the median ESA dose, 8000 IU in 2010, 7,450 IU in 2011 and 7,248 IU in 2012.

\section{Erythropoietin stimulating agents in prevalent peritoneal dialysis patients}

In 2012, the median dose was substantially lower in prevalent PD patients at 4,250 (range 2,231-9,500) IU/week (table 10.4) compared with HD patients.

ESA prescription and association with achieved haemoglobin

For $\mathrm{HD}$ patients, centre level median $\mathrm{Hb}$ is plotted against median ESA dose in figure 10.27 and compliance with the RA standards for $\mathrm{Hb} 100 \mathrm{~g} / \mathrm{L}$ and $120 \mathrm{~g} / \mathrm{L}$ is plotted against median ESA dose in figure 10.28. For these figures, $\mathrm{Hb}$ data was only used for those patients who were receiving an ESA and had dose data available. 
Table 10.4. Summary statistics for haemoglobin, serum ferritin and ESA for prevalent PD patients in 2012

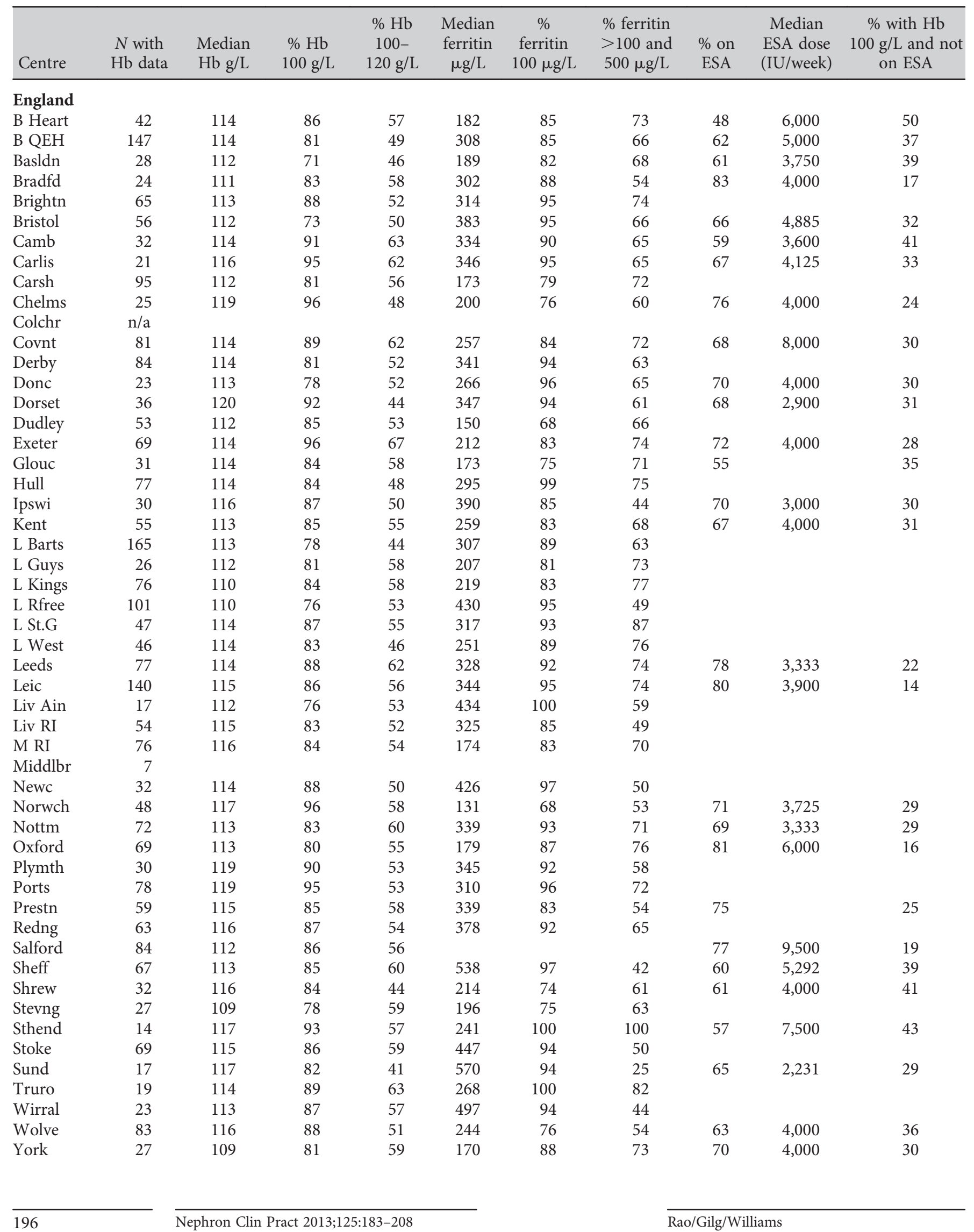


Table 10.4. Continued

\begin{tabular}{|c|c|c|c|c|c|c|c|c|c|c|}
\hline Centre & $\begin{array}{l}N \text { with } \\
\mathrm{Hb} \text { data }\end{array}$ & $\begin{array}{c}\text { Median } \\
\mathrm{Hb} \text { g/L }\end{array}$ & $\begin{array}{c}\% \mathrm{Hb} \\
100 \mathrm{~g} / \mathrm{L}\end{array}$ & $\begin{array}{c}\% \mathrm{Hb} \\
100- \\
120 \mathrm{~g} / \mathrm{L}\end{array}$ & $\begin{array}{l}\text { Median } \\
\text { ferritin } \\
\mu \mathrm{g} / \mathrm{L}\end{array}$ & $\begin{array}{c}\% \\
\text { ferritin } \\
100 \mu \mathrm{g} / \mathrm{L}\end{array}$ & $\begin{array}{l}\% \text { ferritin } \\
>100 \text { and } \\
500 \mu \mathrm{g} / \mathrm{L}\end{array}$ & $\begin{array}{l}\% \text { on } \\
\text { ESA }\end{array}$ & $\begin{array}{l}\text { Median } \\
\text { ESA dose } \\
\text { (IU/week) }\end{array}$ & $\begin{array}{c}\% \text { with } \mathrm{Hb} \\
100 \mathrm{~g} / \mathrm{L} \text { and not } \\
\text { on ESA }\end{array}$ \\
\hline Antrim & 10 & 115 & 100 & 70 & 239 & 80 & 60 & 80 & 3,833 & 20 \\
\hline Belfast & 25 & 114 & 88 & 56 & 221 & 96 & 75 & 80 & 3,000 & 20 \\
\hline Newry & 14 & 108 & 86 & 71 & 192 & 64 & 57 & 86 & 2,458 & 14 \\
\hline \multicolumn{11}{|l|}{ Scotland } \\
\hline Abrdn & 20 & 115 & 85 & 55 & & & & & & \\
\hline Airdrie & 10 & 113 & 90 & 70 & & & & & & \\
\hline D \& Gall & 13 & 115 & 92 & 69 & & & & & & \\
\hline Dundee & 18 & 109 & 78 & 72 & & & & & & \\
\hline Klmarnk & 40 & 111 & 73 & 45 & & & & & & \\
\hline \multicolumn{11}{|l|}{ Wales } \\
\hline Bangor & 14 & 117 & 86 & 43 & 179 & 57 & 50 & 50 & 4,000 & 50 \\
\hline Cardff & 71 & 110 & 87 & 65 & 151 & 67 & 63 & & & \\
\hline Clwyd & 15 & 108 & 73 & 53 & 238 & 86 & 64 & & & \\
\hline Swanse & 54 & 111 & 87 & 69 & 328 & 85 & 63 & 78 & 4,500 & 22 \\
\hline Wrexm & 20 & 121 & 85 & 35 & & & & 55 & 8,000 & 40 \\
\hline England & 2,819 & 114 & 85 & 54 & 288 & 88 & 66 & 69 & 4,500 & 29 \\
\hline N Ireland & 70 & 115 & 91 & 56 & 239 & 88 & 67 & 80 & 3,000 & 20 \\
\hline Scotland & 209 & 114 & 85 & 58 & & & & & & \\
\hline Wales & 174 & 112 & 86 & 60 & 198 & 76 & 64 & 68 & 6,000 & 31 \\
\hline
\end{tabular}

Blank cells denote centres excluded from analyses due to poor data completeness or low patient numbers or because the data item was not available n/a - no PD patients

ESA data only shown for those centres for which the \% on ESA was $45 \%$ or more

For ferritin and for ESA the overall averages given are for E, W \& NI not UK

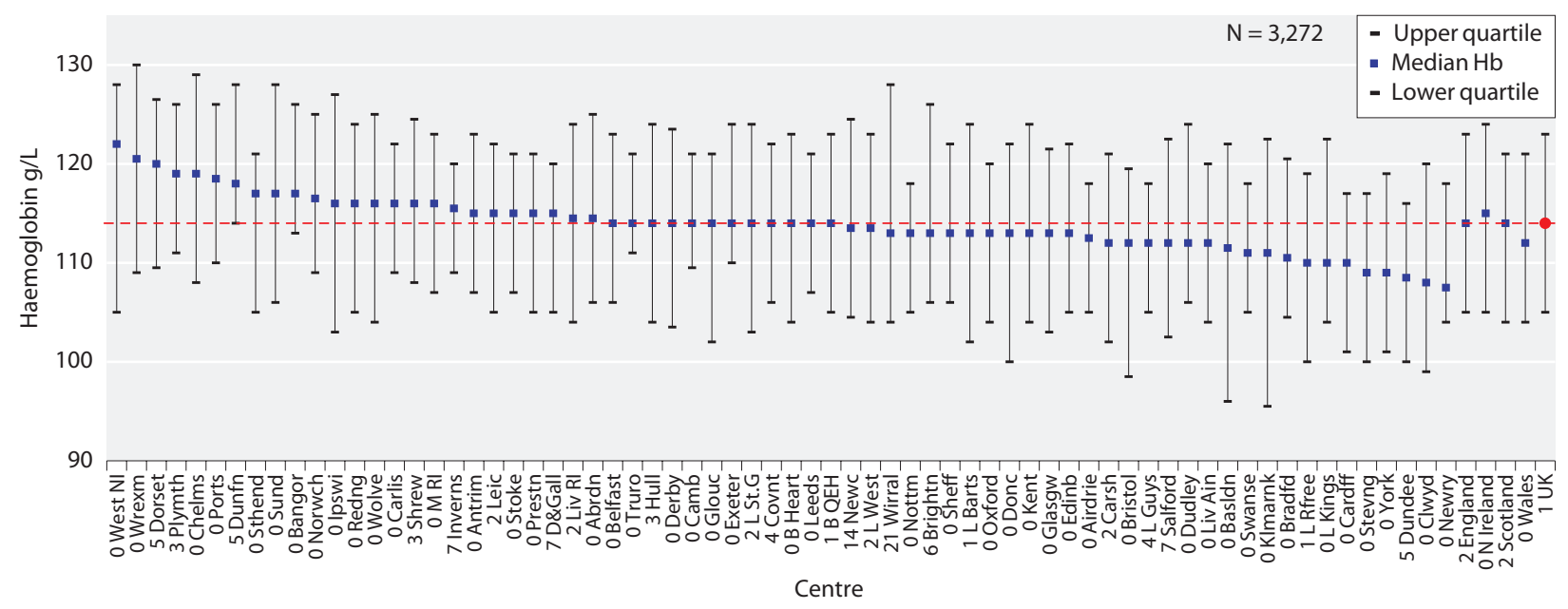

Fig. 10.12. Median haemoglobin in patients treated with PD by centre in 2012 


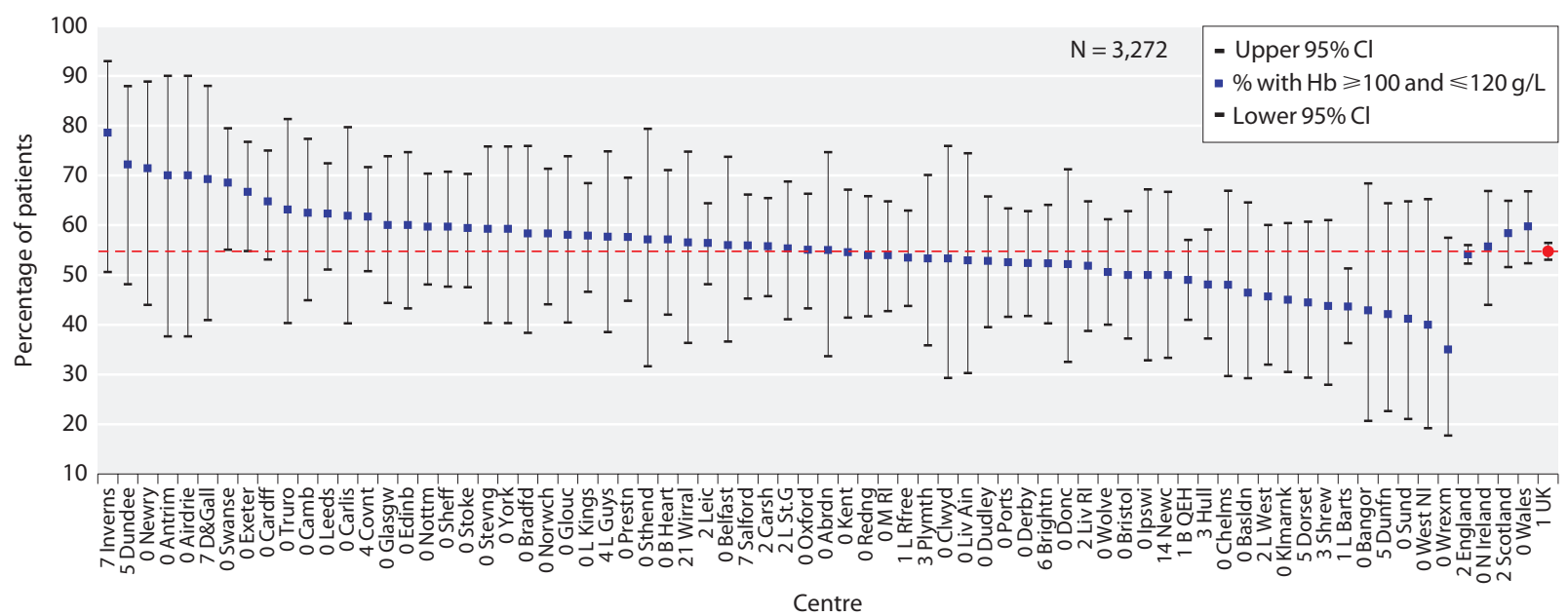

Fig. 10.13. Percentage of PD patients with $\mathrm{Hb} 100$ and $120 \mathrm{~g} / \mathrm{L}$ by centre in 2012

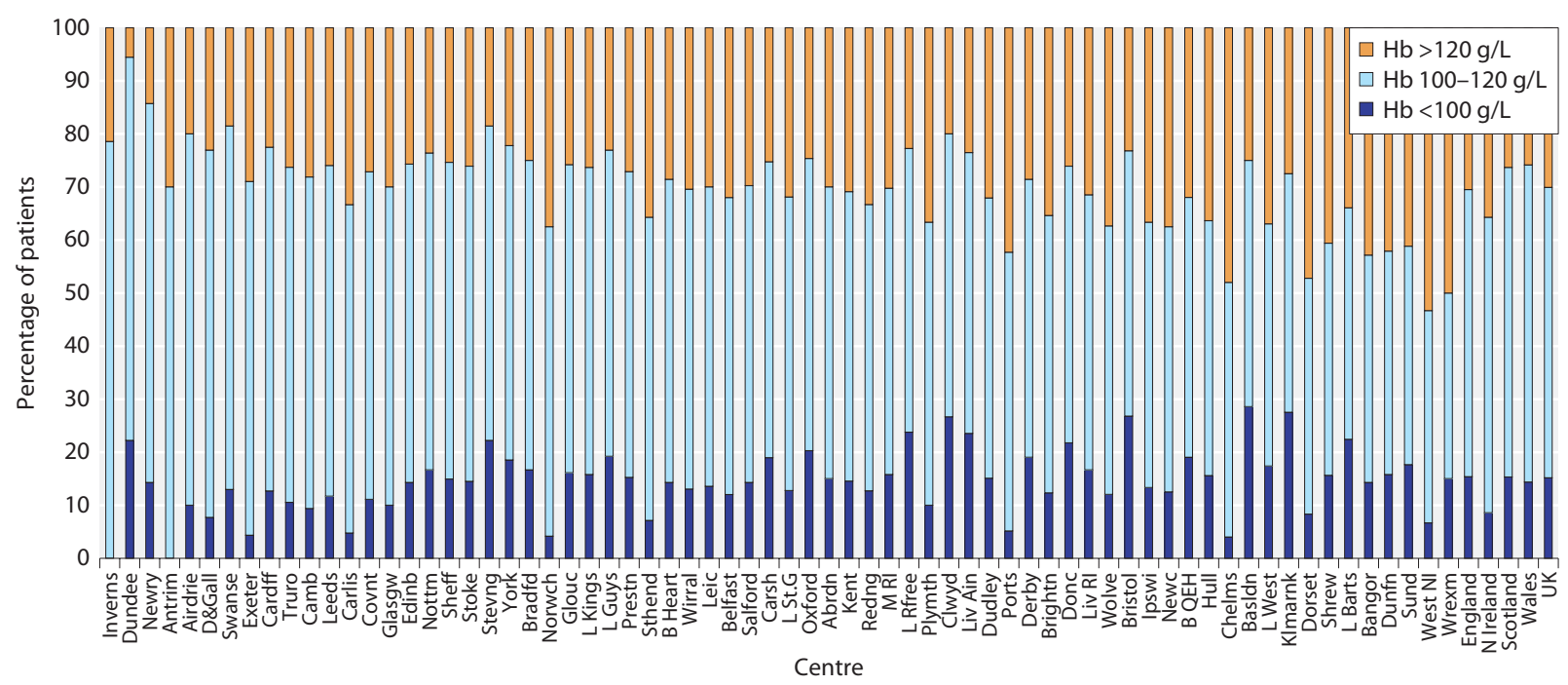

Fig. 10.14. Distribution of haemoglobin in patients treated with PD by centre in 2012

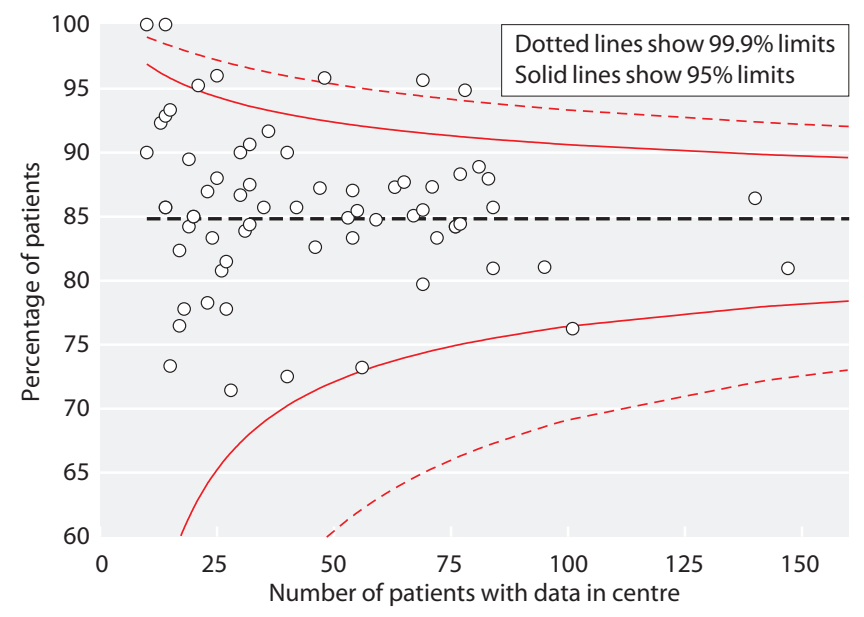

Fig. 10.15. Funnel plot of percentage of $\mathrm{PD}$ patients with $\mathrm{Hb}$ $100 \mathrm{~g} / \mathrm{L}$ by centre in 2012

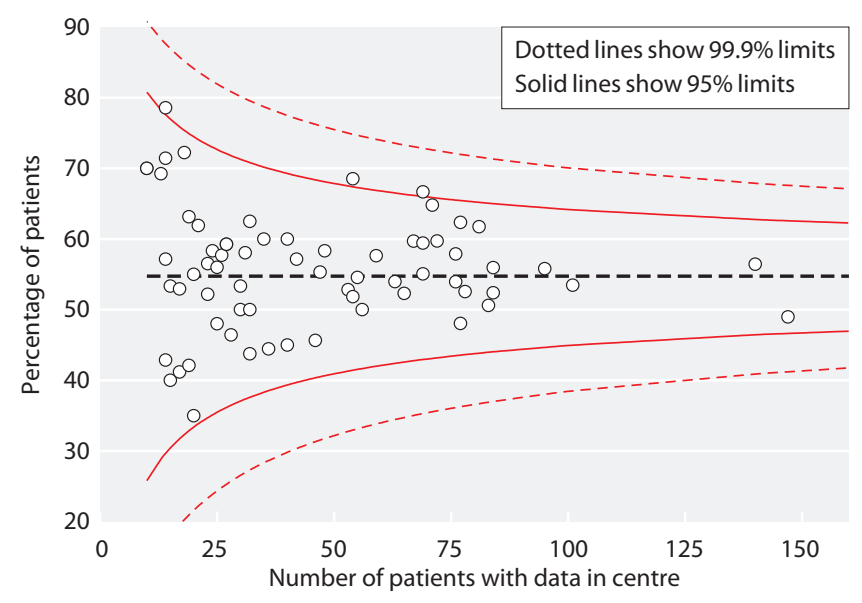

Fig. 10.16. Funnel plot of percentage of $\mathrm{PD}$ patients with $\mathrm{Hb}$ $100 \mathrm{~g} / \mathrm{L}$ and $120 \mathrm{~g} / \mathrm{L}$ by centre in 2012 


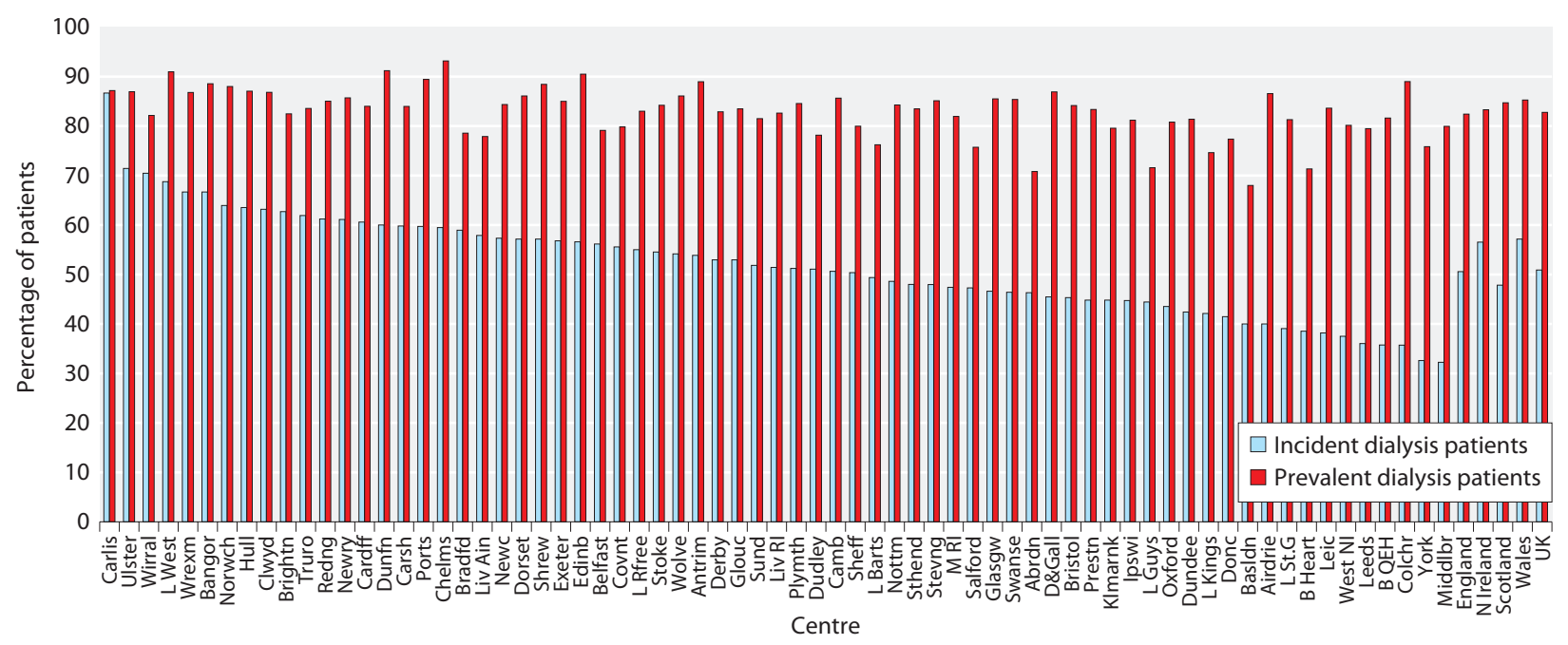

Fig. 10.17. Percentage of incident and prevalent dialysis patients with $\mathrm{Hb} 100 \mathrm{~g} / \mathrm{L}$ by centre in 2012

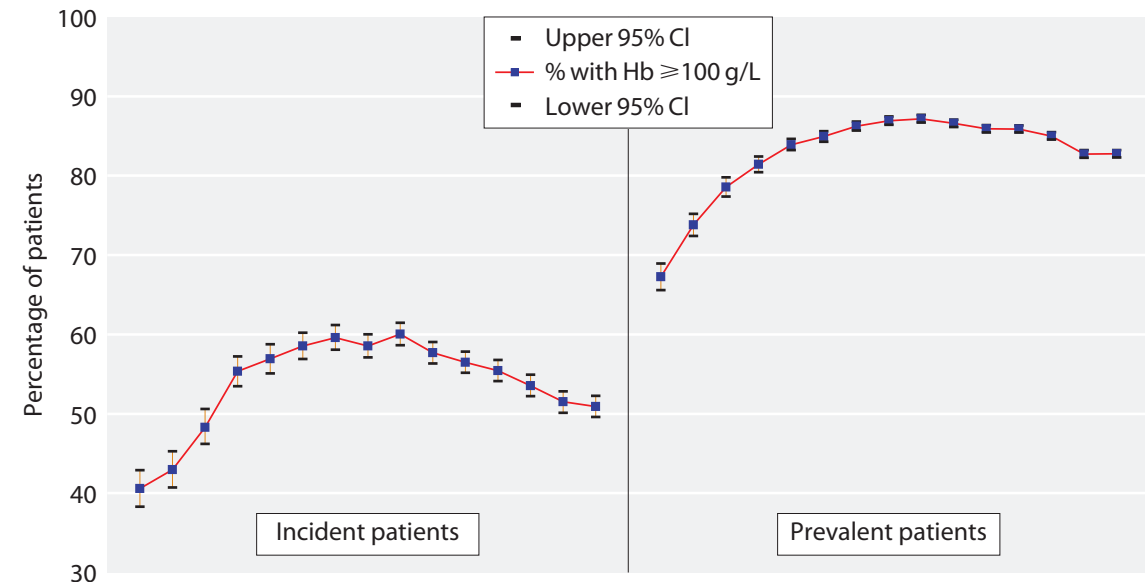

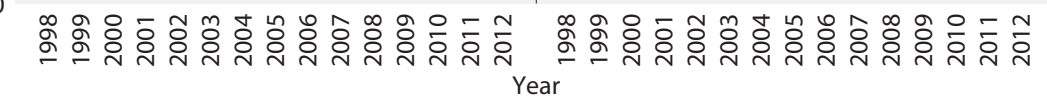

Fig. 10.18. Percentage of incident and prevalent dialysis patients (1998-2012) with $\mathrm{Hb} 100 \mathrm{~g} / \mathrm{L}$

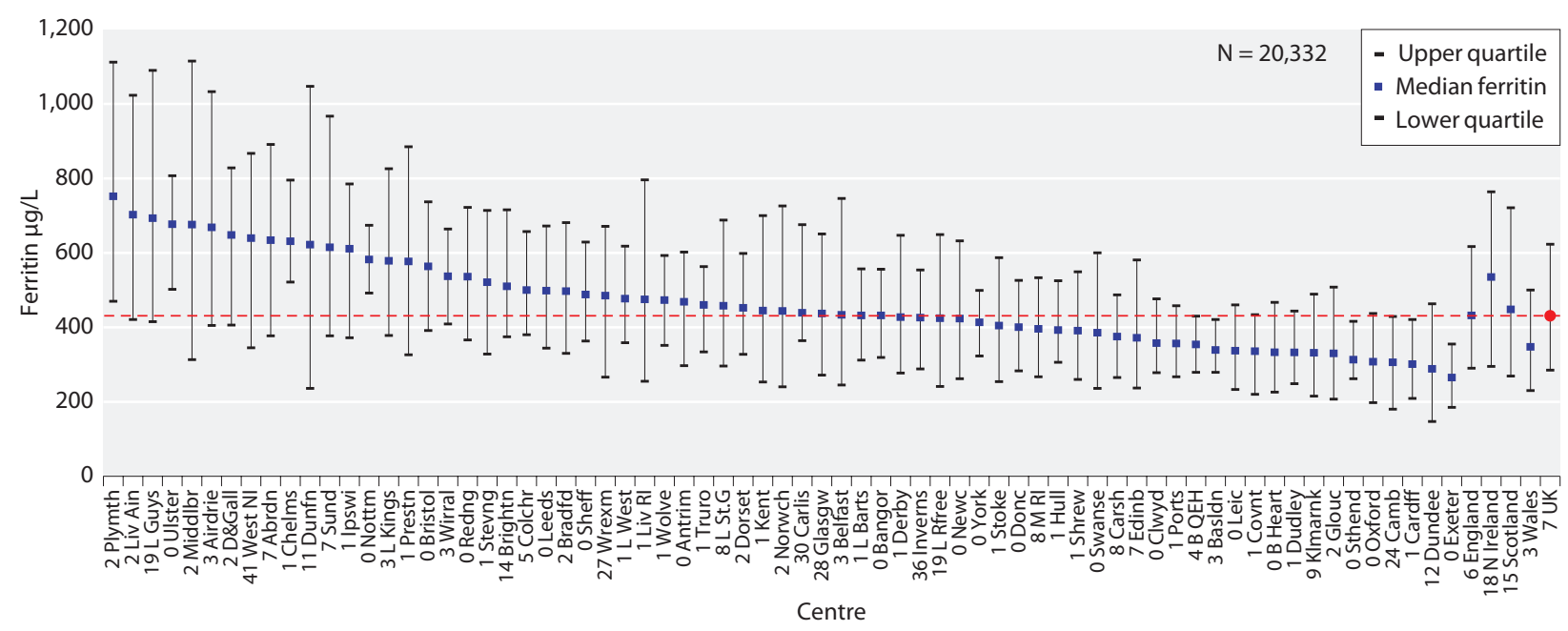

Fig. 10.19. Median ferritin in patients treated with HD by centre in 2012 


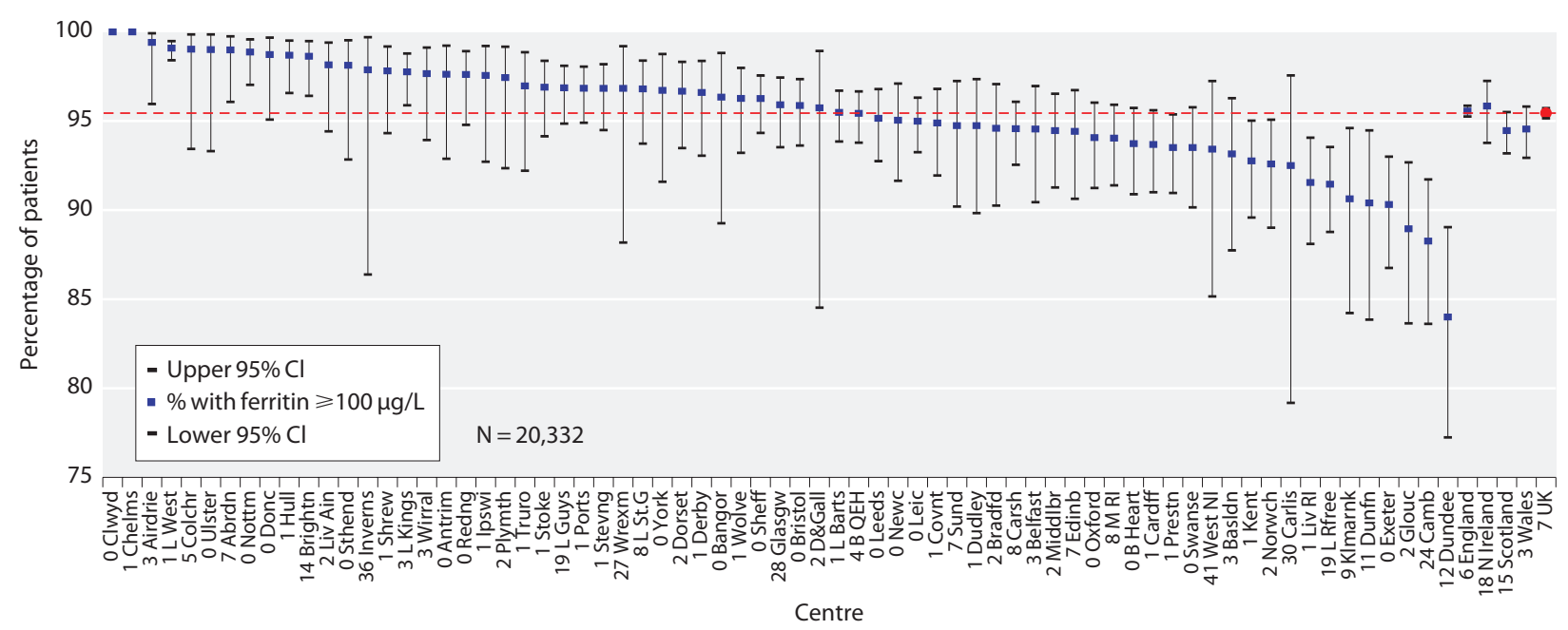

Fig. 10.20. Percentage of HD patients with ferritin $100 \mu \mathrm{g} / \mathrm{L}$ by centre in 2012

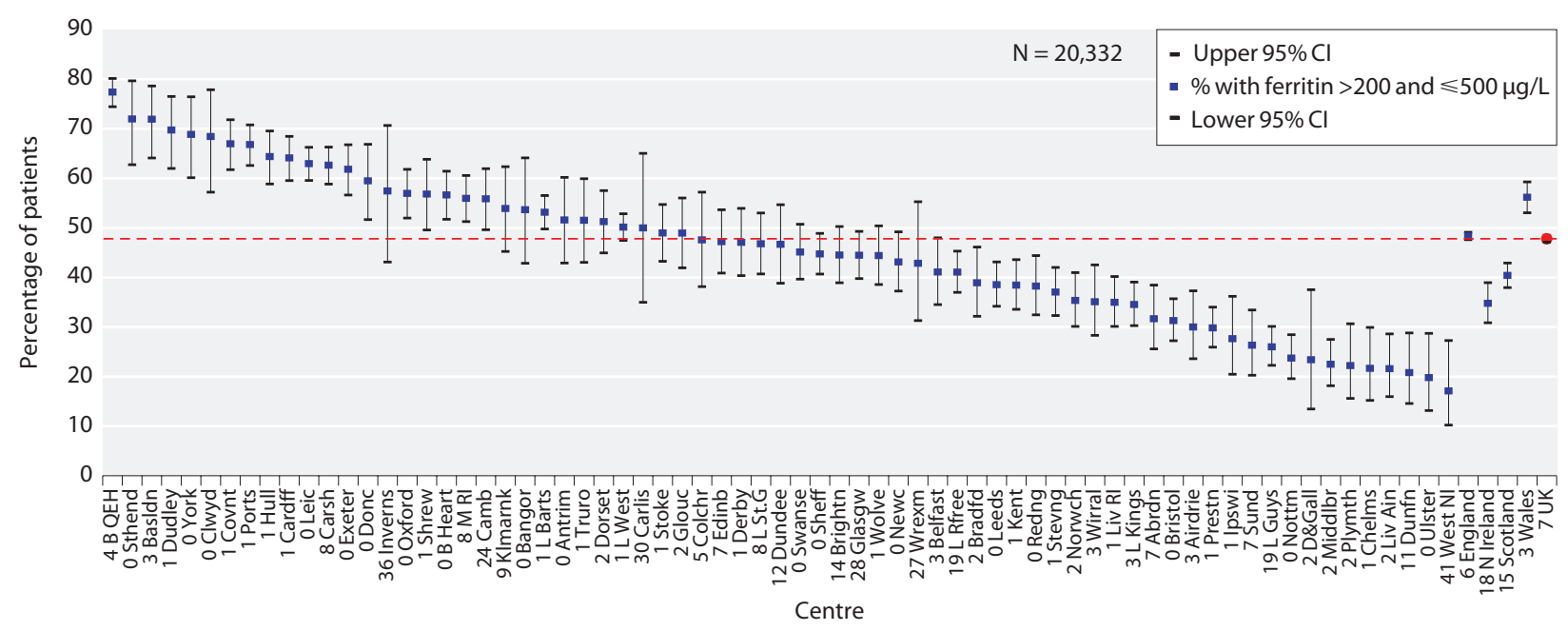

Fig. 10.21. Percentage of HD patients with ferritin $>200 \mu \mathrm{g} / \mathrm{L}$ and $500 \mu \mathrm{g} / \mathrm{L}$ by centre in 2012

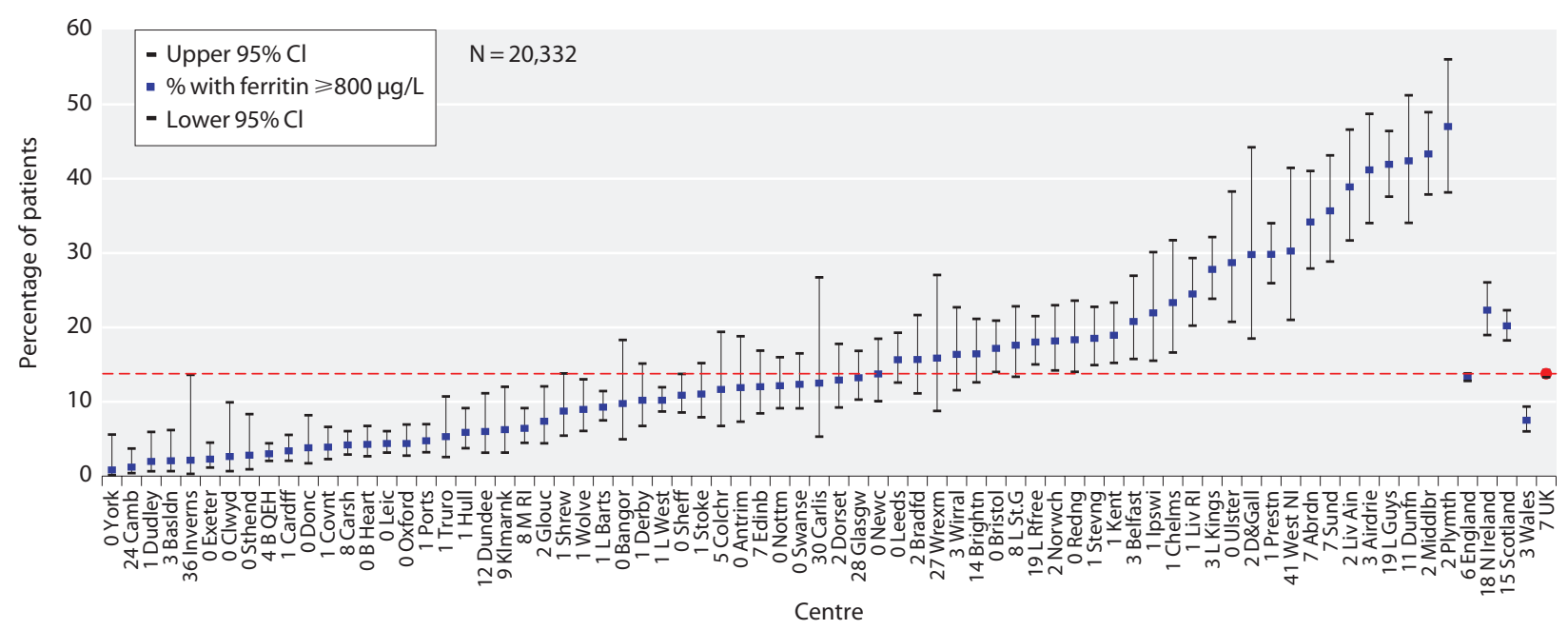

Fig. 10.22. Percentage of HD patients with ferritin $800 \mu \mathrm{g} / \mathrm{L}$ by centre in 2012 


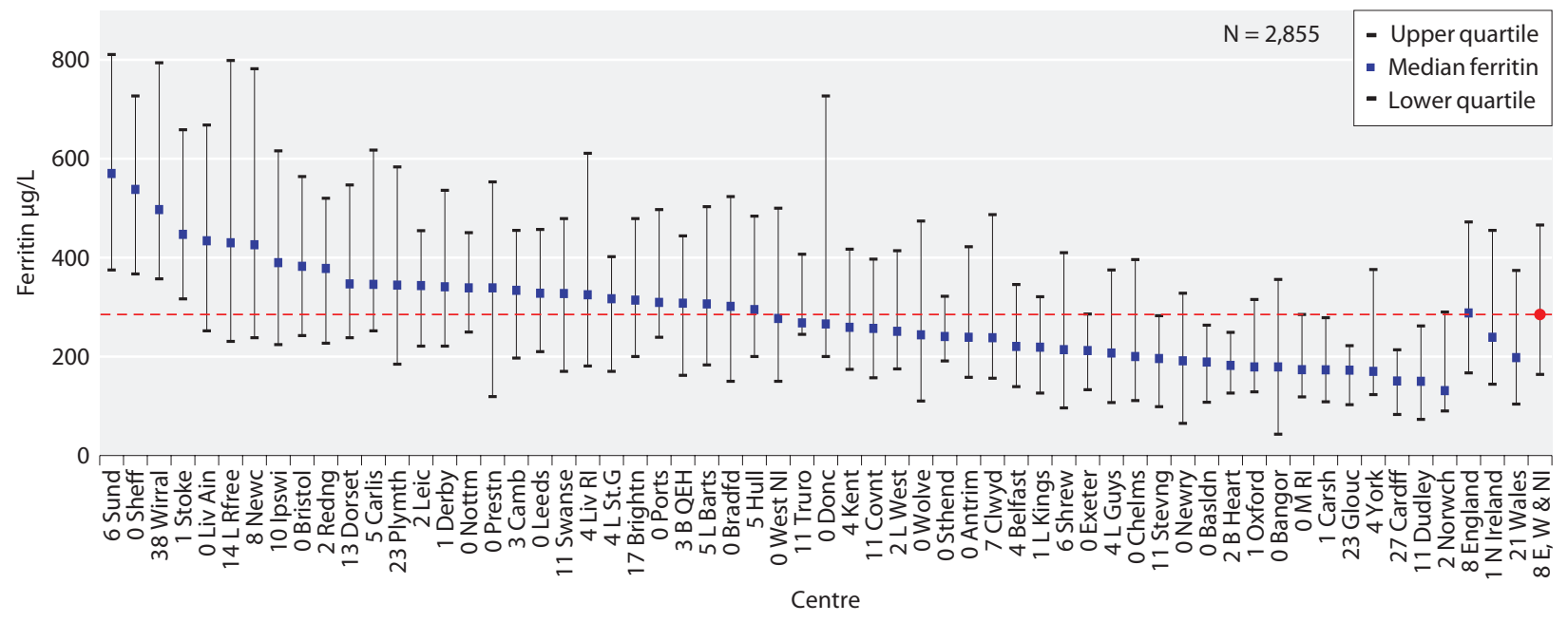

Fig. 10.23. Median ferritin in patients treated with PD by centre in 2012

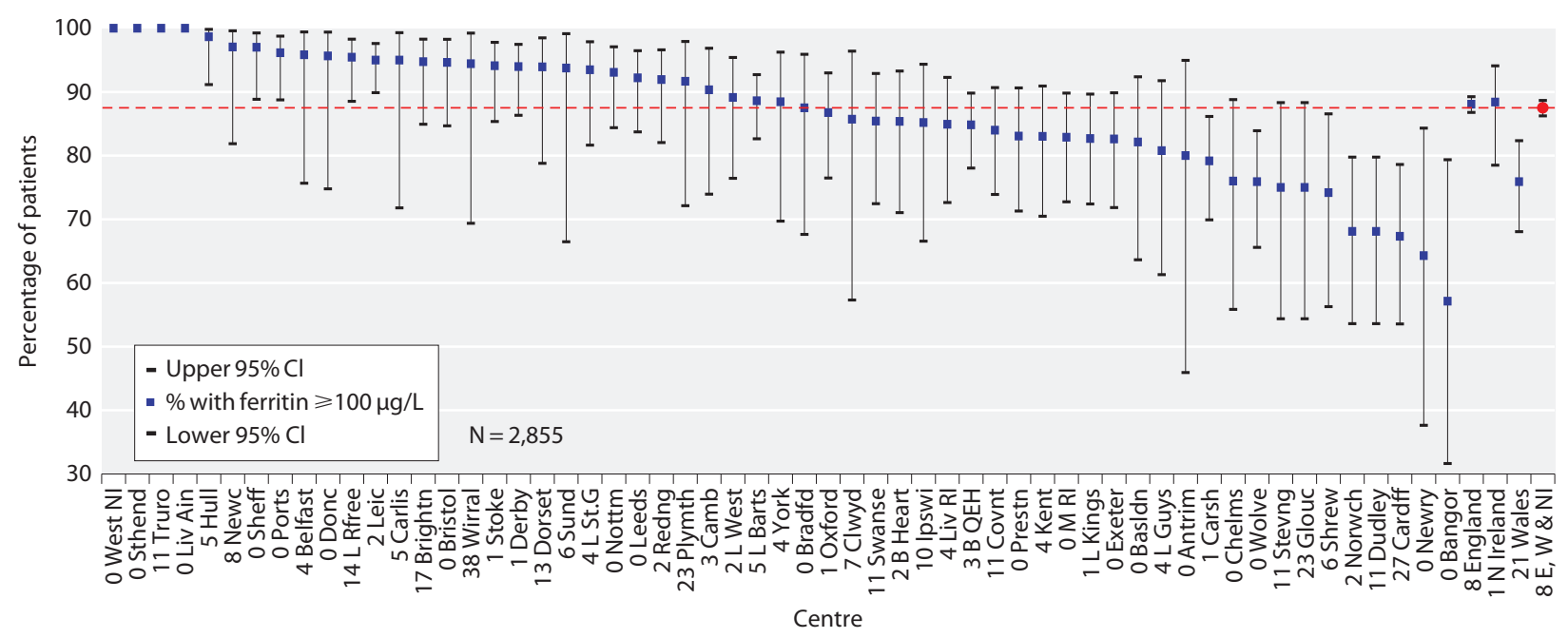

Fig. 10.24. Percentage of PD patients with ferritin $100 \mu \mathrm{g} / \mathrm{L}$ by centre in 2012

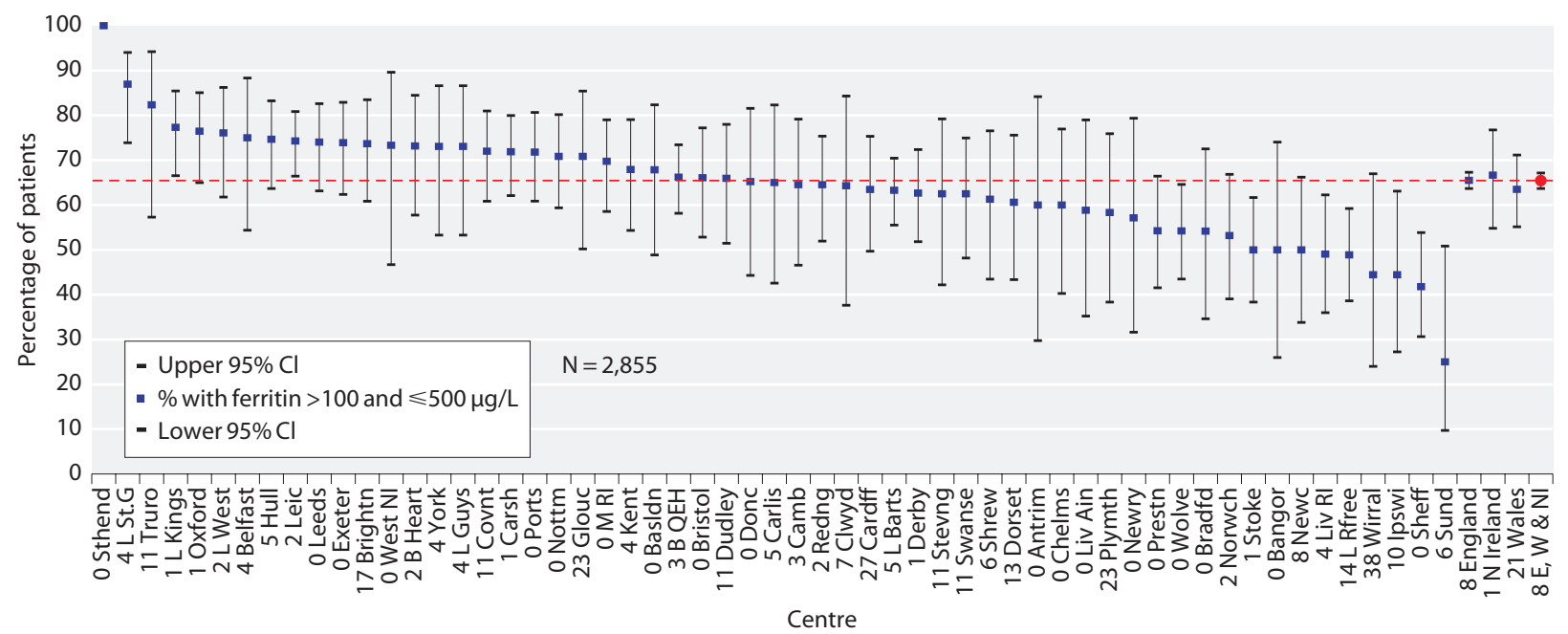

Fig. 10.25. Percentage of PD patients with ferritin $>100 \mu \mathrm{g} / \mathrm{L}$ and $500 \mu \mathrm{g} / \mathrm{L}$ by centre in 2012 


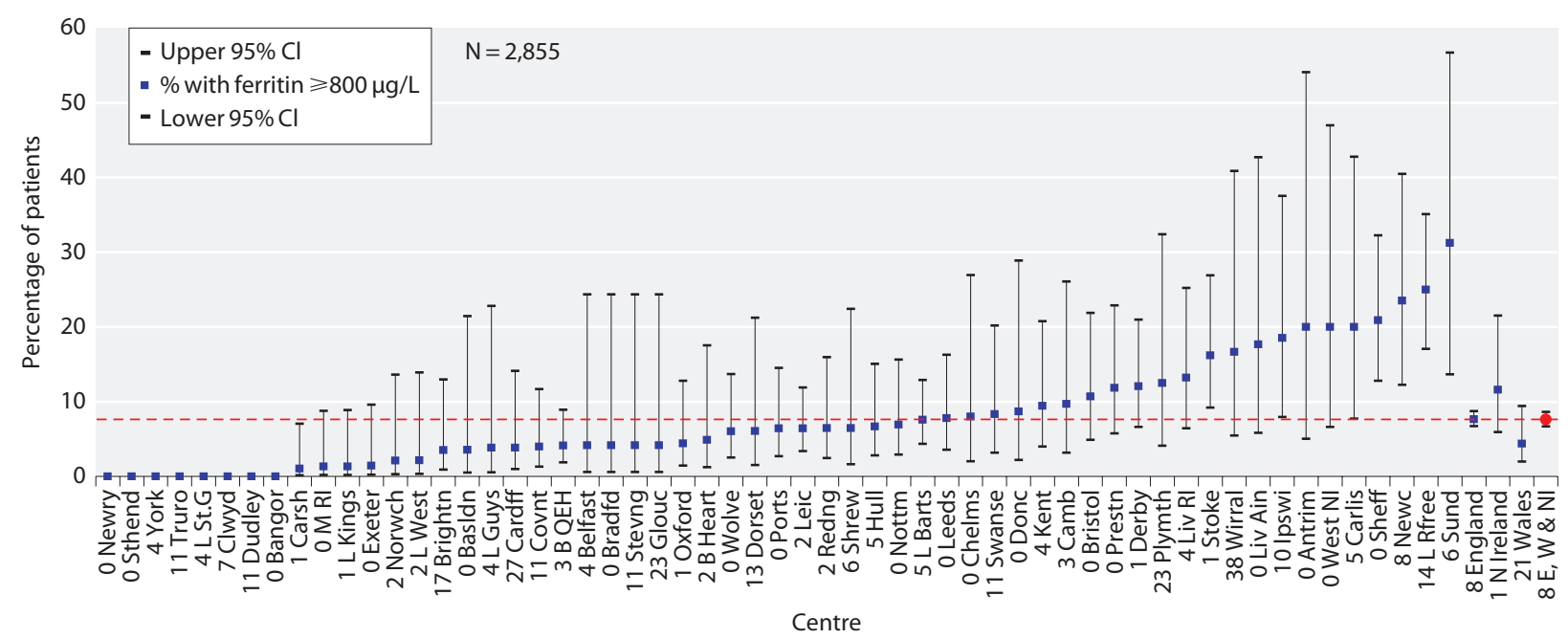

Fig. 10.26. Percentage of $\mathrm{PD}$ patients with ferritin $800 \mu \mathrm{g} / \mathrm{L}$ by centre in 2012

There was no strong relationship in either figure.

It is known that not all patients treated with dialysis who have a $\mathrm{Hb}$ above $120 \mathrm{~g} / \mathrm{L}$ are receiving ESA. It has been suggested that it may be inappropriate to include those patients not receiving ESA within the group not meeting this RA target. There are two reasons: firstly, the high $\mathrm{Hb}$ remains outside the control of the clinician, and secondly, the recent trials suggesting that it may be detrimental to achieve a high $\mathrm{Hb}$ in renal patients were based only upon patients treated with ESAs $[13,14]$.

Figures 10.29 and 10.30 show the percentages of HD and PD patients in each centre whose $\mathrm{Hb}$ lies above, within or below the RA guidelines of $100-120 \mathrm{~g} / \mathrm{L}$. These charts also show the proportion of patients with a $\mathrm{Hb}$ above the upper limit who were receiving, or were not receiving an ESA. These analyses are restricted to the centres with acceptable ESA returns as stipulated above. These figures show that $25 \%$ of HD patients had

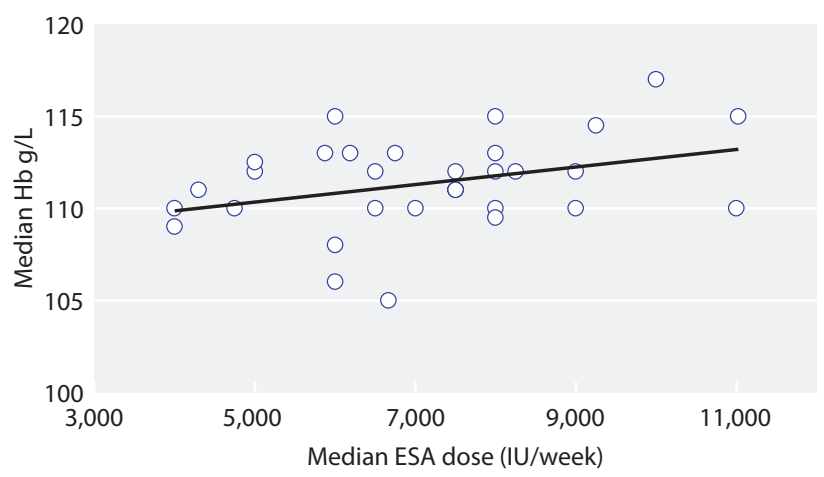

Fig. 10.27. Median $\mathrm{Hb}$ versus median ESA dose in $\mathrm{HD}$ patients on ESA, by centre in 2012 a $\mathrm{Hb}>120 \mathrm{~g} / \mathrm{L}$. Most of these patients (79\%) were on ESAs. Whereas for PD, 30\% of patients had a $\mathrm{Hb}$ $>120 \mathrm{~g} / \mathrm{L}$, but only about $51 \%$ of these were on ESAs.

ESA prescription: age and modality associations

The proportion of patients on an ESA was higher for HD (87\%) than PD (69\%) and this difference was present and similar across all age groups (figure 10.31). The proportion of patients who maintained a $\mathrm{Hb} 100 \mathrm{~g} / \mathrm{L}$ without requiring ESA (by age group and modality) is shown in figure 10.32. This was highest in the 45-54 age group both for $\mathrm{HD}$ at $13.6 \%$ (95\% CI: $12-15.5 \%)$ and $\mathrm{PD}$ at $33.8 \%$ (95\% CI: $28-40 \%)$.

\section{ESAs and time on renal replacement therapy}

The percentage of patients on ESA by time on RRT and dialysis modality is shown in figure 10.33 . This is a cross-sectional analysis at the final quarter of 2012.

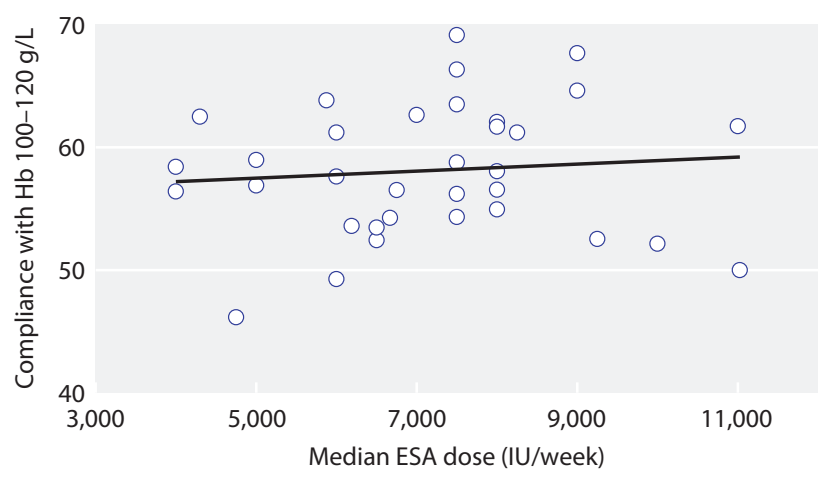

Fig. 10.28. Compliance with $\mathrm{Hb} 100-120$ g/L versus median ESA dose in HD patients on ESA, by centre in 2012 


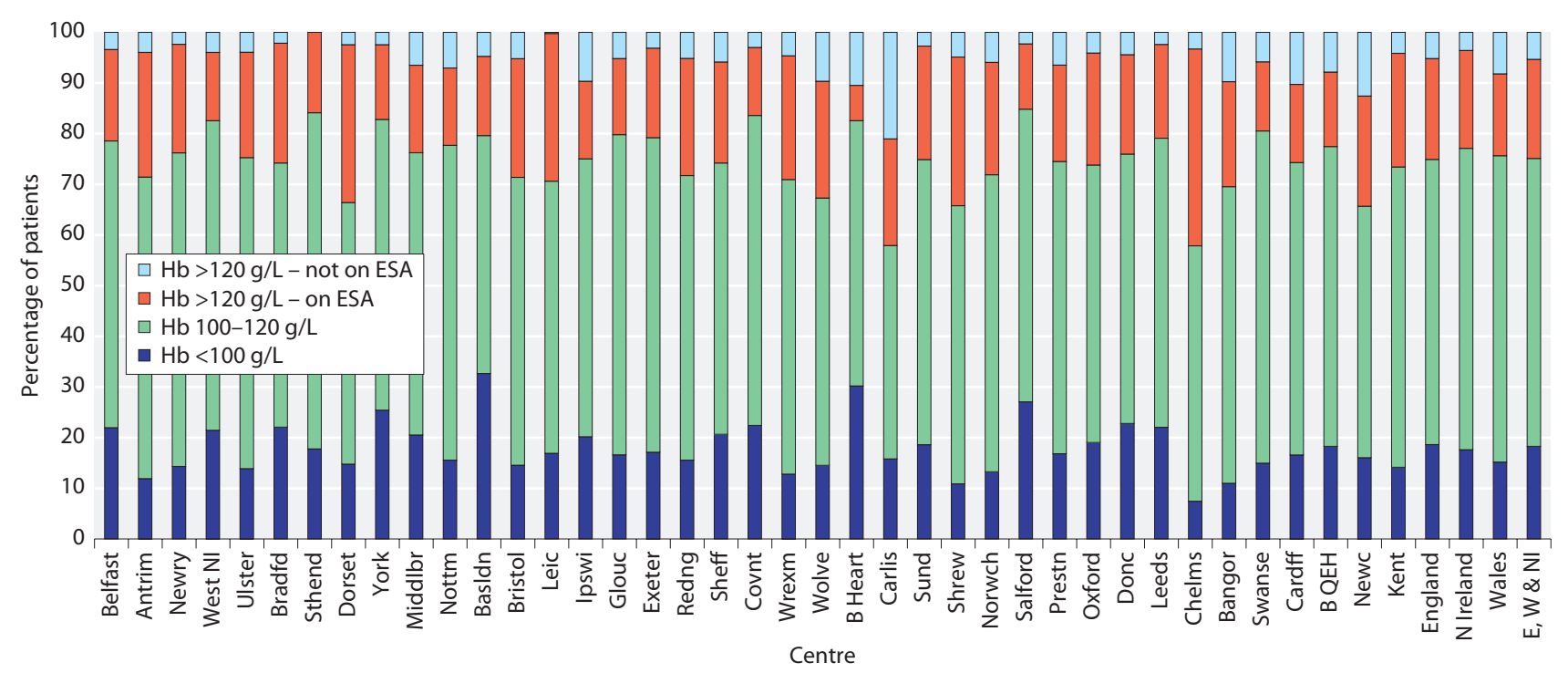

Fig. 10.29. Distribution of haemoglobin in patients treated with $\mathrm{HD}$ and the proportion of patients with $\mathrm{Hb}>120 \mathrm{~g} / \mathrm{L}$ receiving ESA by centre in 2012

Patients who had previously changed RRT modality were included in this analysis. The proportion of PD patients requiring ESA rises with duration of RRT from $69 \%$ after $3-12$ months, to $81 \%$ after 10 or more years. This almost certainly reflects loss of residual renal function. For at least the first 10 years on RRT, a greater percentage of HD patients are receiving ESA treatment than patients on PD for any given duration on RRT.

\section{Resistance to ESA therapy}

Figure 10.34 shows the frequency distribution of weekly ESA dose by treatment modality adjusted for weight. Data regarding prevalence of ESA resistance in the literature in the ERF population is very sparse. RA guidelines define resistance to ESA therapy as 'failure to reach the target $\mathrm{Hb}$ level despite SC epoetin dose $>300 \mathrm{IU} / \mathrm{kg} /$ week (450 IU/ $/ \mathrm{kg} /$ week IV epoetin) or darbepoetin dose $>1.5 \mathrm{mcg} / \mathrm{kg} /$ week'. For the purposes

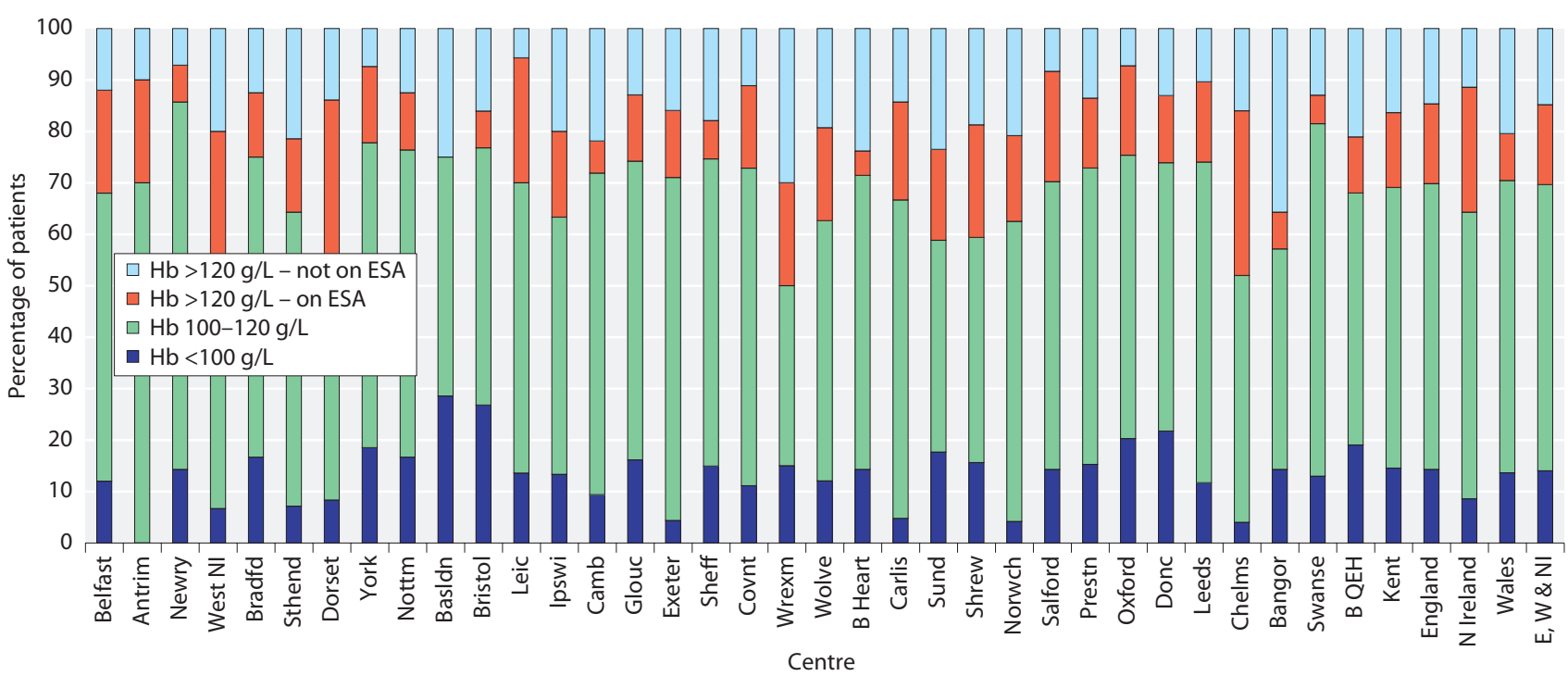

Fig. 10.30. Distribution of haemoglobin in patients treated with PD and the proportion of patients with $\mathrm{Hb}>120 \mathrm{~g} / \mathrm{L}$ receiving ESA by centre in 2012 


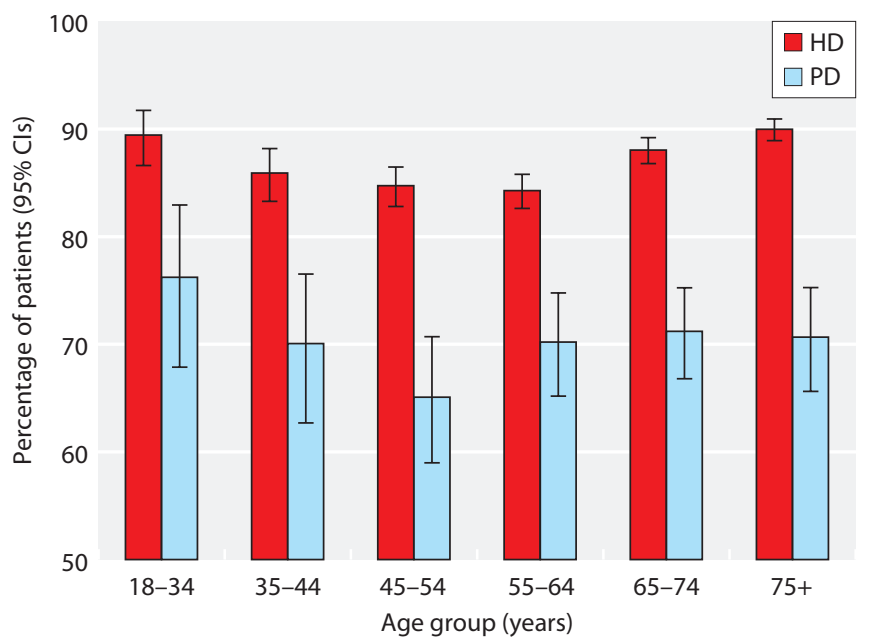

Fig. 10.31. Percentage of dialysis patients on ESA, by age group and treatment modality (2012)

of this analysis the centres were restricted to those with good completeness for weight (over 75\%) and ESA dose data (33 centres for HD and 22 centres for PD). As per the above definition and assuming that HD patients largely receive ESA intravenously and PD patients receive ESA subcutaneously, the prevalence of high doses of ESA was $1.0 \%(N=72)$ and $2.2 \%(N=12)$ for $\mathrm{HD}$ and $\mathrm{PD}$ patients respectively. For these patients the dose range for $\mathrm{HD}$ was 453-772 IU/kg/week and for PD 312-535 $\mathrm{IU} / \mathrm{kg} /$ week. For patients on HD with high ESA doses, $45 \%(N=32)$ had $\mathrm{Hb}<100 \mathrm{~g} / \mathrm{L}$ and $28 \%$ were within $100-120 \mathrm{~g} / \mathrm{L}$. For patients on PD with high ESA doses, $25 \%(N=3)$ had a $\mathrm{Hb}<100 \mathrm{~g} / \mathrm{L}$ and $67 \%$ were within

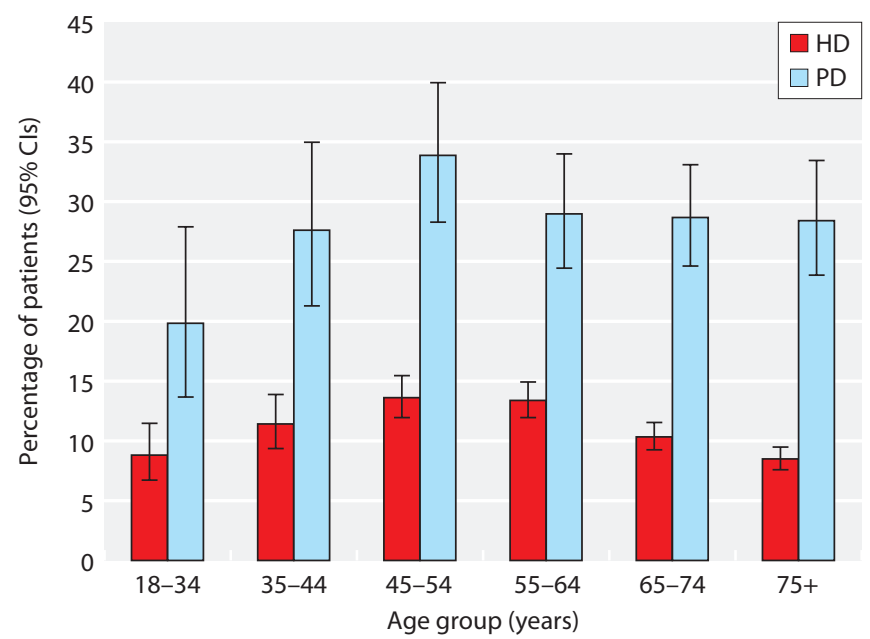

Fig. 10.32. Percentage of whole cohort (2012) who are not on ESA and have $\mathrm{Hb} 100 \mathrm{~g} / \mathrm{L}$, by age group and treatment modality

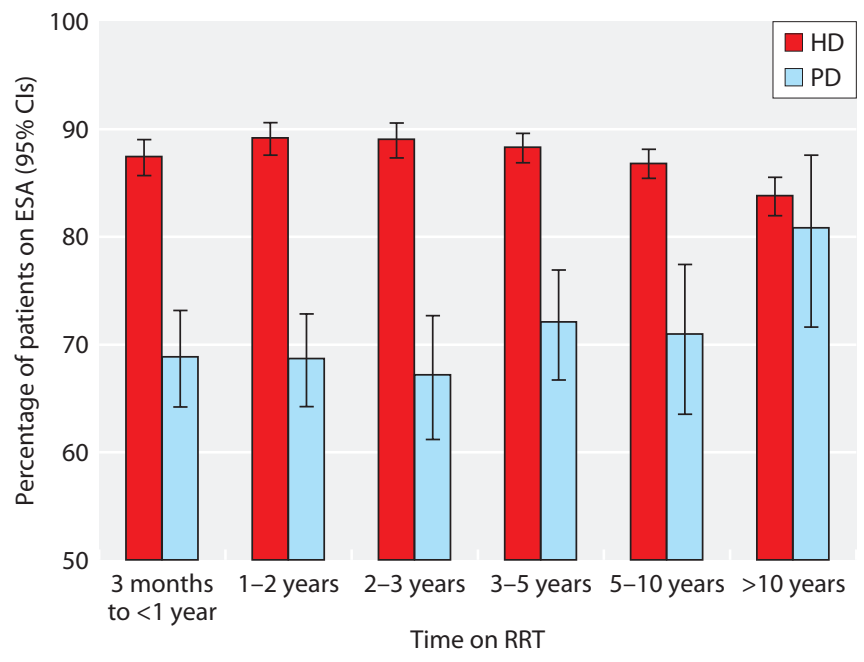

Fig. 10.33. Percentage of patients on ESA by time on RRT (2012)

$100-120 \mathrm{~g} / \mathrm{L}$. The percentage of patients with ESA resistance, defined by those failing to reach target $\mathrm{Hb}>100 \mathrm{~g} / \mathrm{L}$ were $0.5 \%$ for $\mathrm{HD}$ and $0.6 \%$ for PD. Caution needs to be applied when interpreting these results as the numbers for the above calculations are small.

\section{Success with guideline compliance}

Compliance with current minimum standards by year (1998 to 2012) is shown in figure 10.35 for prevalent patients (by treatment modality).

The Renal Association guidelines state that centres should audit the 'Proportion of patients on renal replacement therapy with $\mathrm{Hb}$ level $<100 \mathrm{~g} / \mathrm{L}$ who are

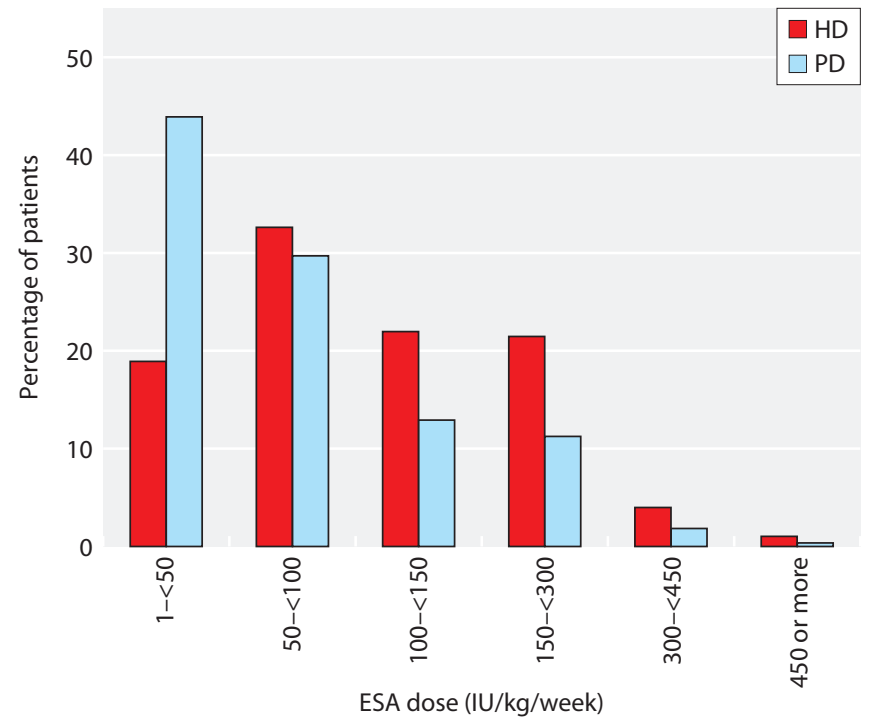

Fig. 10.34. Frequency distribution of mean weekly ESA dose corrected for weight in 2012 


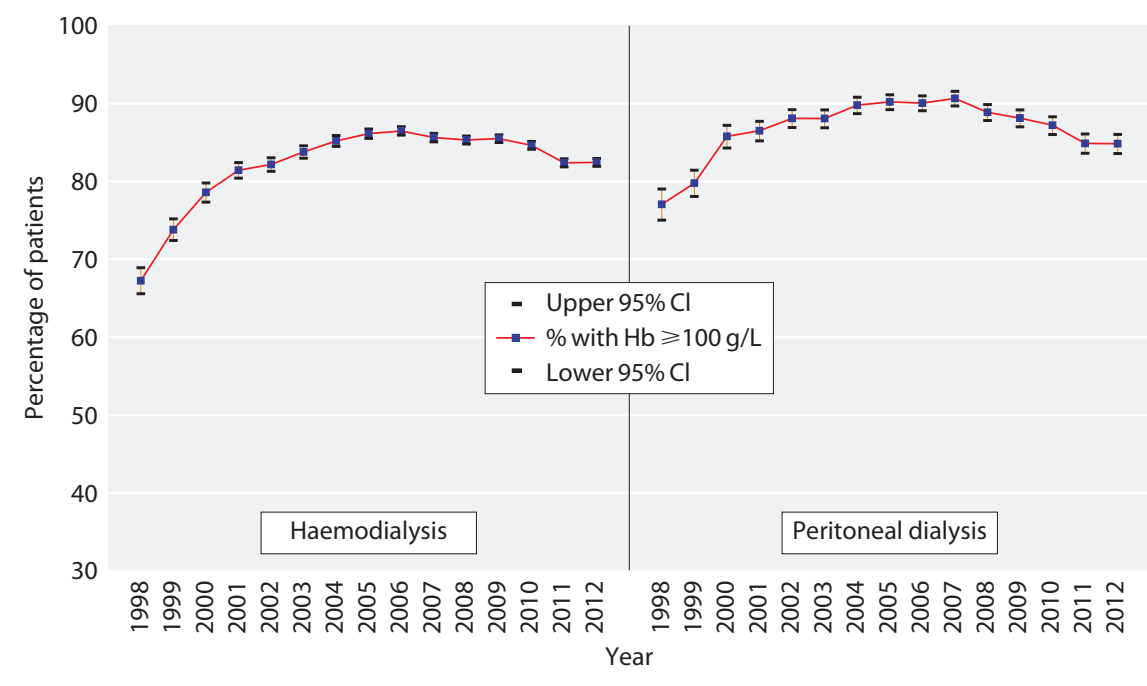

Fig. 10.35. Percentage of prevalent $\mathrm{HD}$ and PD patients (1998-2012) with $\mathrm{Hb}$ $100 \mathrm{~g} / \mathrm{L}$ not prescribed an ESA'. Figure 10.36 shows the percentage of anaemic patients $(\mathrm{Hb}<100 \mathrm{~g} / \mathrm{L})$ receiving an ESA. A minority of patients had a $\mathrm{Hb}<100 \mathrm{~g} / \mathrm{L}$ and were not receiving ESA therapy. Across the age groups this was between $7-10 \%$ for HD patients and $2-13 \%$ for PD patients. There are several potential explanations for this. Treatment with ESA may have been stopped in patients who were unresponsive or avoided in those with malignancy. Others may have been on ESA treatment but not had it recorded.

The Renal Association guideline states that centres should audit the 'Proportion of patients with serum ferritin levels $<100 \mu \mathrm{g} / \mathrm{L}$ treated with an ESA' \& 'The proportion of patients treated with an ESA with

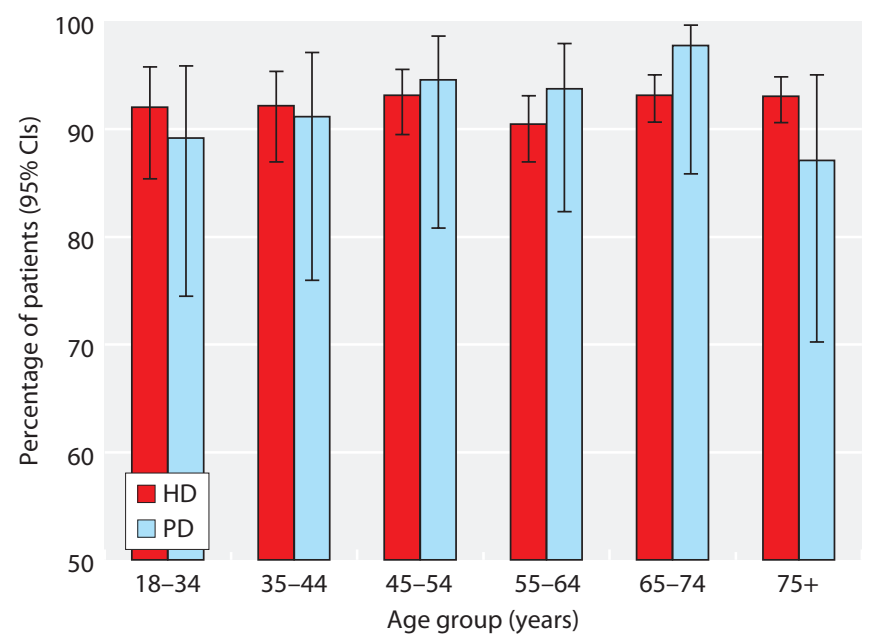

Fig. 10.36. Percentage of patients with $\mathrm{Hb}<100 \mathrm{~g} / \mathrm{L}$ who were on ESA, by age group and treatment modality (2012)
$\boldsymbol{H} \boldsymbol{b}>\mathbf{1 2 0} \mathbf{g} / \mathbf{L}$ '. Table 10.5 shows that the percentage of all patients treated with an ESA and having $\mathrm{Hb}$ $>120 \mathrm{~g} / \mathrm{L}$ ranged between $7-39 \%$ for HD and between $0-33 \%$ for PD. For HD, there was a small percentage of patients having ferritin levels $<100 \mu \mathrm{g} / \mathrm{L}$ and being on an ESA (0-7\%). The percentages were somewhat higher for PD (0-21\%).

Renal Association guidelines state that 'Each renal unit should audit the type, route and frequency of administration and weekly dose of ESA prescribed'. Table 10.6 shows the percentage completeness for type, route and frequency of administration for centres $(N=40)$ reporting ESA data. The completeness was generally good for drug type and dose but patchy for frequency and route of administration.

\section{Discussion}

Anaemia is one of the major problems that contribute to high comorbidity and poor outcome in dialysis patients. Since the introduction of human recombinant erythropoietin for treating CKD-related anaemia over two decades ago, attention has shifted from treating severe anaemia in dialysis patients to preventing anaemia pre-dialysis and to correcting anaemia within defined target limits. Renal centres strive to meet the Renal Association standards in order to prevent adverse outcomes associated with low $\mathrm{Hb}$ such as impaired quality of life, increased hospitalisation, increased cardiovascular events and increased cardiovascular and all-cause mortality. 
Table 10.5. Percentage of patients with serum ferritin levels $<100 \mu \mathrm{g} / \mathrm{L}$ and on ESA and percentage of patients with $\mathrm{Hb}>120 \mathrm{~g} / \mathrm{L}$ and on ESA by modality

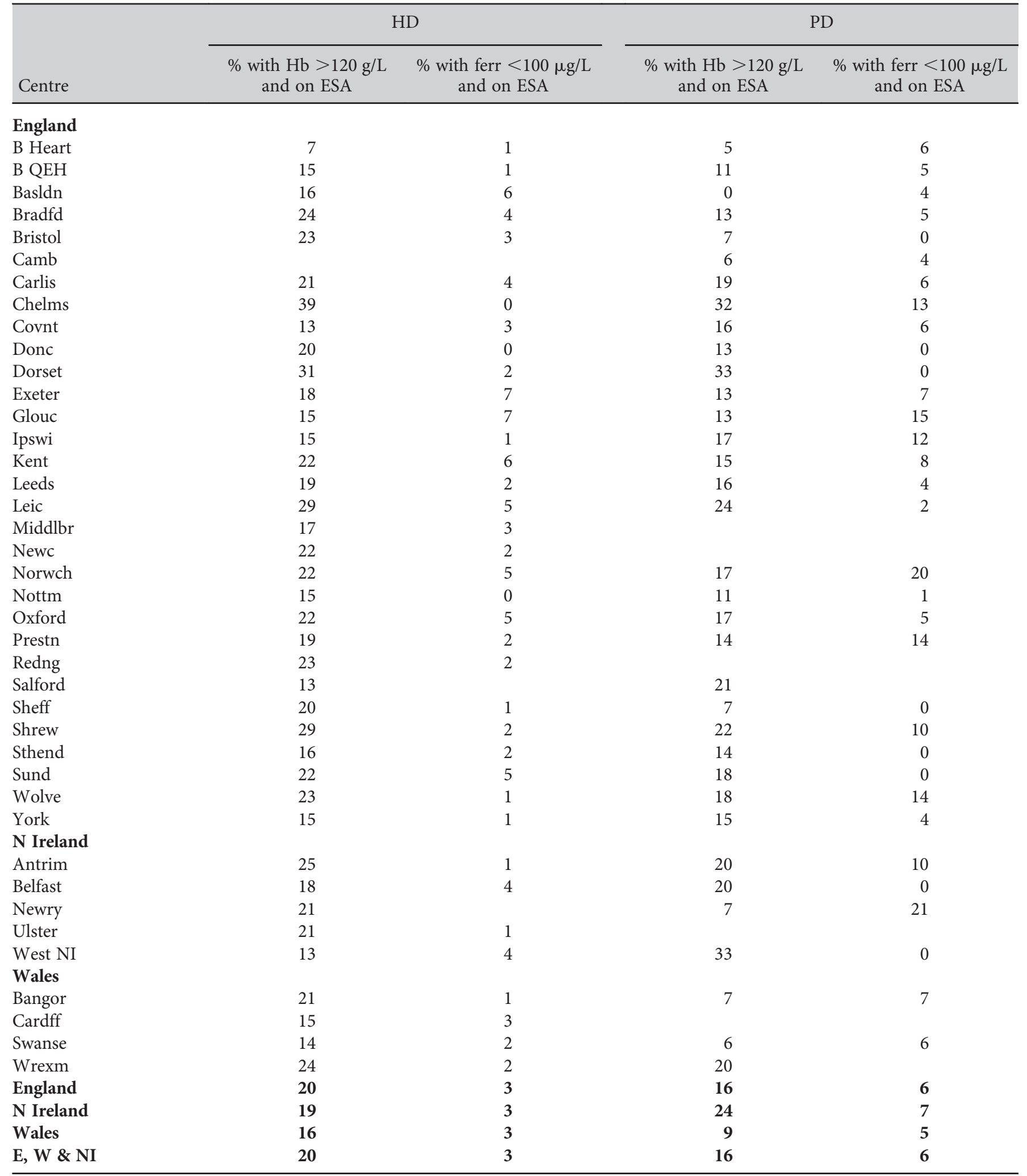

Blank cells denote centres excluded from analyses due to poor completeness or small numbers with data 
Table 10.6. Percentage completeness for type, dose, route and frequency of administration of ESA

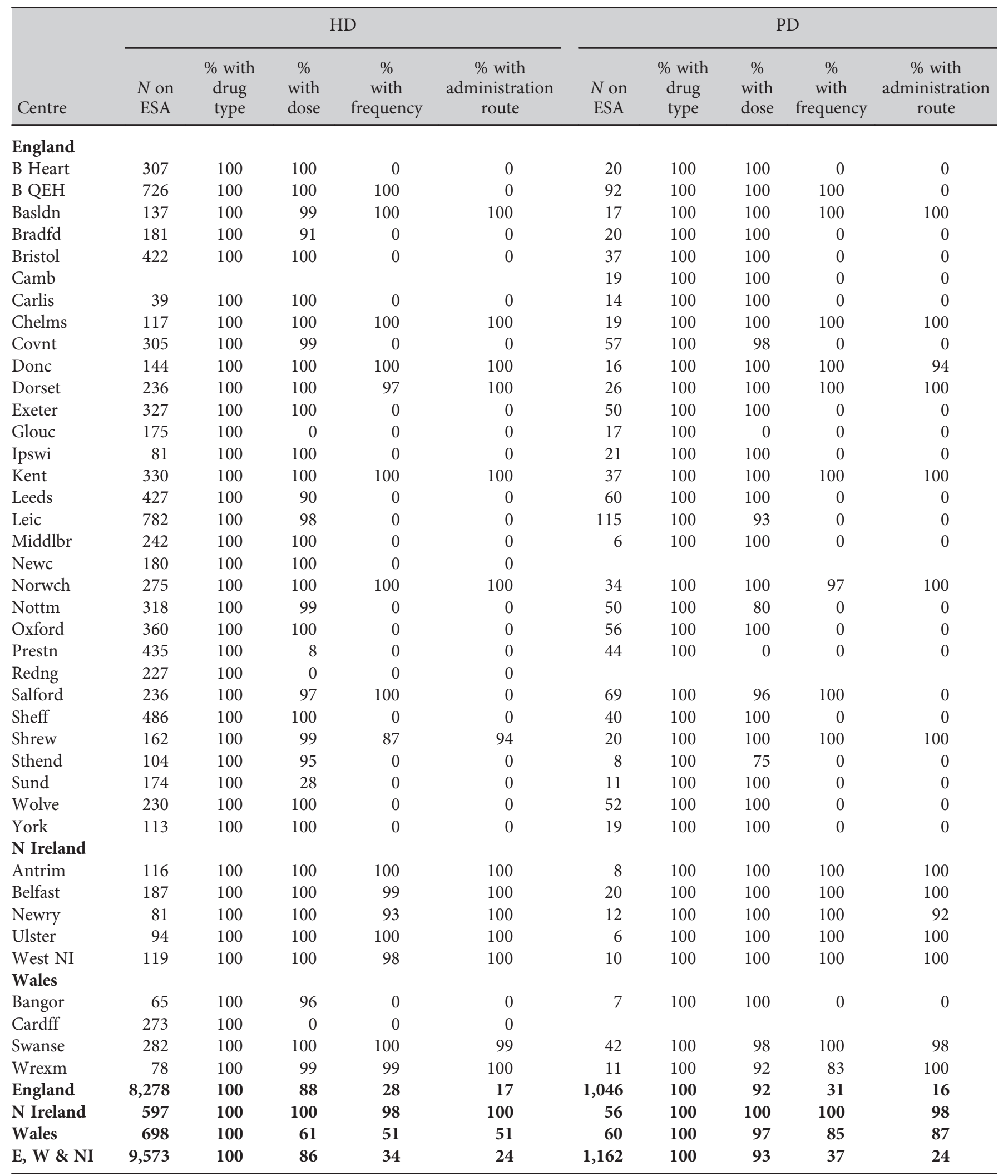

Blank cells denote centres excluded from analyses due to poor completeness or small numbers with data 
Haemoglobin outcomes for patients on $\mathrm{HD}$ and PD in the UK were largely compliant with the RA minimum standard of $\mathrm{Hb} 100 \mathrm{~g} / \mathrm{L}$ ( $82 \%$ and $85 \%$ respectively). As would be anticipated, a greater proportion of prevalent patients $(83 \%)$ than incident patients $(51 \%)$ had a $\mathrm{Hb}$ $100 \mathrm{~g} / \mathrm{L}$ in 2012. In the UK, the median $\mathrm{Hb}$ of patients on $\mathrm{HD}$ was $112 \mathrm{~g} / \mathrm{L}$ with an IQR of $103-121 \mathrm{~g} / \mathrm{L}$, and the median $\mathrm{Hb}$ of patients on PD was $114 \mathrm{~g} / \mathrm{L}$ with an IQR of $105-123 \mathrm{~g} / \mathrm{L}$.

Compliance with advice regarding iron stores as reflected by ferritin remained stable in the UK with $95 \%$ of HD patients and $88 \%$ of PD patients achieving a serum ferritin greater than $100 \mu \mathrm{g} / \mathrm{L}$.

The analysis of ESA usage is limited by incomplete data returns. From the available data, $87 \%$ of HD patients and $69 \%$ of PD patients were on ESA treatment in England, Wales and Northern Ireland. The percentage of patients treated with an ESA and having $\mathrm{Hb}>120 \mathrm{~g} / \mathrm{L}$ ranged between centres from $7-39 \%$ for $\mathrm{HD}$ and from $0-33 \%$ for PD. There was a small percentage of patients with ferritin levels $<100 \mu \mathrm{g} / \mathrm{L}$ and receiving an ESA. There was substantial variation between centres in the average dose of ESA prescribed. Attainment of $\mathrm{Hb}$ targets correlates poorly with median ferritin and ESA usage.

Resistance to ESA has consistently been shown to be associated with an increased risk of death and cardiovascular events in CKD patients [14-17]. There is for the first time an attempt to describe the prevalence of ESA resistance in the UK and this was $0.5 \%$ and $0.6 \%$ for $\mathrm{HD}$ and PD patients respectively. Bearing in mind the limitations of relatively small numbers involved in the calculations, one possible reason that could explain the low prevalence is that this group of patients have poor survival. This again emphasises the need for better data returns and with improved completeness future analysis could look into whether this translates to poor patient outcomes for the UK dialysis population.

Conflicts of interest: none

\section{References}

1 KDIGO clinical practice guideline for anemia in chronic kidney disease. Summary of recommendations statements. Kidney International Supplements 2012;2:283-287

2 Department of Health Renal Team National Service Framework for Renal Services: Part One - Dialysis and transplantation, 2004, Department of Health: London

3 Renal Association. Treatment of adults and children with renal failure: standards and audit measures. 3rd Edition., 2002, Royal College of Physicians of London and the Renal Association: London

4 Locatelli F, et al. Anaemia management in patients with chronic kidney disease: a position statement by the Anaemia Working Group of European Renal Best Practice (ERBP). Nephrology Dialysis Transplantation 2009;24(2):348-354

5 National Institute for Health and Clinical Excellence (NICE). Anaemia management in people with chronic kidney disease (CG114), 2011

6 Renal Association Clinical Practice Guidelines Committee: Haemodialysis, 5th Edition. 2010. http://www.renal.org/clinical/guidelinessection/ haemodialysis.aspx

7 Kidney Disease: Improving Global Outcomes (KDIGO) Anemia Work Group. KDIGO Clinical Practice Guideline for Anemia in Chronic Kidney Disease. Kidney inter 2012:2(suppl 1);279-335

8 Movilli E, et al. Predialysis versus postdialysis hematocrit evaluation during erythropoietin therapy. American journal of kidney diseases: the official journal of the National Kidney Foundation 2002:39(4);850853

9 Kalantar-Zadeh K, et al. Diagnosis of iron deficiency anemia in renal failure patients during the post-erythropoietin era. American Journal of Kidney Diseases 1995;26(2):292-299
10 Eschbach JW, et al. Correction of the Anemia of End-Stage Renal Disease with Recombinant Human Erythropoietin. New England Journal of Medicine 1987:316(2);73-78

11 Singh AK, et al. Correction of Anemia with Epoetin Alfa in Chronic Kidney Disease. New England Journal of Medicine 2006:355(20);20852098

12 Drüeke TB, et al. Normalization of Hemoglobin Level in Patients with Chronic Kidney Disease and Anemia. New England Journal of Medicine 2006:355(20):2071-2084

13 Pfeffer MA, et al. A Trial of Darbepoetin Alfa in Type 2 Diabetes and Chronic Kidney Disease. New England Journal of Medicine 2009: 361(21);2019-2032

14 Gomez-Alamillo C, et al. Erythropoietin Resistance as Surrogate Marker of Graft and Patient Survival in Renal Transplantation: 3-Year Prospective Multicenter Study. Transplantation Proceedings 2010; 42(8):2935-2937

15 Chung S, et al. Relationship between erythropoietin resistance index and left ventricular mass and function and cardiovascular events in patients on chronic hemodialysis. Hemodialysis International 2012; 16(2):181187

16 Panichi V, et al. Anaemia and resistance to erythropoiesis-stimulating agents as prognostic factors in haemodialysis patients: results from the RISCAVID study. Nephrology Dialysis Transplantation, 2011;26(8): 2641-2648

17 Solomon SD, et al. Erythropoietic Response and Outcomes in Kidney Disease and Type 2 Diabetes. New England Journal of Medicine 2010;363(12):1146-1155 